UNIVERSIDADE DE SÃO PAULO

INSTITUTO DE RELAÇÕES INTERNACIONAIS

PROGRAMA DE PÓS-GRADUAÇÃO EM RELAÇÕES INTERNACIONAIS

JOÃO PAULO HERNANDES TEODORO

A PROPRIEDADE INTELECTUAL NOS ACORDOS PREFERENCIAIS DE COMÉRCIO FIRMADOS PELOS ESTADOS UNIDOS COM PAÍSES LATINOAMERICANOS NA DÉCADA DE 2000: MOTIVAÇÕES E RESULTADOS NORMATIVOS 
UNIVERSIDADE DE SÃO PAULO

INSTITUTO DE RELAÇÕES INTERNACIONAIS

PROGRAMA DE PÓS-GRADUAÇÃO EM RELAÇÕES INTERNACIONAIS

\title{
A PROPRIEDADE INTELECTUAL NOS ACORDOS PREFERENCIAIS DE COMÉRCIO FIRMADOS PELOS ESTADOS UNIDOS COM PAÍSES LATINO- AMERICANOS NA DÉCADA DE 2000: MOTIVAÇÕES E RESULTADOS NORMATIVOS
}

\author{
JOÃO PAULO HERNANDES TEODORO
}

Dissertação apresentada ao Programa de PósGraduação em Relações Internacionais do Instituto de Relações Internacionais da Universidade de São Paulo para a obtenção do título de "Mestre em Ciências - Programa de Pós-Graduação em Relações Internacionais"

Orientador: Prof. Dr. Yi Shin Tang

\section{Versão corrigida.}

A versão original se encontra disponível na Biblioteca do Instituto de Relações Internacionais e na Biblioteca Digital de Teses e Dissertações da USP, documentos impresso e eletrônico. 
Autorizo a reprodução e divulgação total ou parcial deste trabalho, por qualquer meio convencional ou eletrônico, para fins de estudo e pesquisa, desde que citada a fonte.

Teodoro, João Paulo Hernandes

A propriedade intelectual nos acordos preferenciais de comércio firmados pelos Estados Unidos com países latino-americanos na década de 2000: motivações e resultados normativos / Yi Shin Tang - orientador. - São Paulo, 2015.

$65 p$.

Dissertação (Mestrado) - Universidade de São Paulo, 2015.

1. Acordos preferenciais de comércio. 2. Propriedade Intelectual. 3. Estados Unidos. 4. América Latina. I. Título. 
Nome: TEODORO, João Paulo Hernandes

Título: A propriedade intelectual nos acordos preferenciais de comércio firmados pelos Estados Unidos com países latino-americanos na década de 2000: motivações e resultados normativos

Dissertação apresentada ao Programa de PósGraduação em Relações Internacionais do Instituto de Relações Internacionais da Universidade de São Paulo para a obtenção do título de "Mestre em Ciências - Programa de Pós-Graduação em Relações Internacionais"

Aprovado em:

Banca examinadora

Prof $^{a}$ Dra. Michelle Ratton Sanchez Badin Instituição: FGV-SP

Julgamento:

Assinatura:

Prof. Dr. Feliciano de Sá Guimarães

Instituição: IRI-USP

Julgamento:

Assinatura:

Prof. Dr. Yi Shin Tang

Instituição: IRI-USP

Julgamento:

Assinatura: 


\section{AGRADECIMENTOS}

Agradeço a todas e todos que, direta ou indiretamente, contribuíram para que eu concluísse esta dissertação e as demais atividades concernentes ao mestrado; aos professores da UNESP que me orientaram no início da minha vida acadêmica; aos professores das disciplinas que cursei na USP, aos que participaram da minha qualificação e aos que participarão da minha defesa; à sempre dedicada professora Janina Onuki, que, sempre de modo tão competente, não economiza nas críticas e sugestões; à professora Cristiane Lucena, com quem realizei o estágio de docência; ao meu orientador, Yi Shin Tang, que ao longo da pesquisa, de modo sempre solícito, me indicou caminhos; à CAPES e à FAPESP ${ }^{1}$, agências que, cada qual a seu tempo, me permitiram desenvolver, do melhor modo que pude, esta pesquisa. Estendo meus agradecimentos também às funcionárias do SAS, em particular à Carla Magalhães Cucolo; aos funcionários da Secretaria de Pós-graduação e Pesquisa do IRI; e às funcionárias da biblioteca do IRI (todos dedicados, competentes e indispensáveis). Por fim, agradeço aos amigos de sempre, de dentro e de fora das RI, e à minha família, todos sempre ao meu lado. A todos os citados dedico este trabalho.

\footnotetext{
1 “Processo n² 2013/10931-1, Fundação de Amparo à Pesquisa do Estado de São Paulo (FAPESP)".
} 


\section{RESUMO}

TEODORO, J.P.H. A propriedade intelectual nos acordos preferenciais de comércio firmados pelos Estados Unidos com países latino-americanos na década de 2000: motivações e resultados normativos. 2015. 65 f. Dissertação (Mestrado) - Instituto de Relações Internacionais, Universidade de São Paulo, São Paulo, 2015.

$\mathrm{O}$ artigo analisa os capítulos sobre propriedade intelectual dos acordos preferenciais de comércio firmados pelos Estados Unidos com países da América Latina na década de 2000, discutindo tanto as motivações do país para a assinatura dos mesmos (e inserindo tal discussão em um framework teórico) quanto as implicações dos acordos para os direitos de propriedade intelectual de seus signatários. Nesse sentido, apresenta algumas teorias acerca das características intrínsecas a instituições internacionais multilaterais, em contraste com as bilaterais e regionais; tais teorias afirmam que os estados, ao lidar com resultados indesejados de características institucionais, modificam instituições (ou criam novas instituições) de acordo com seus objetivos. Em seguida, apresenta o resultado de um levantamento bibliográfico acerca das motivações estadunidenses para a assinatura dos mencionados acordos preferenciais de comércio, com ênfase nas motivações relacionadas aos direitos de propriedade intelectual; tal resultado é complementado com a análise dos documentos primários pertinentes. Por fim, compara o conteúdo dos mencionados capítulos entre si; também os compara com o Acordo TRIPS da OMC. $\mathrm{O}$ artigo conclui que as motivações estadunidenses coincidem com as expectativas teóricas; que os capítulos analisados são substancialmente diferentes do Acordo TRIPS; que eles contêm diversas diferenças entre si (as quais são, em parte, decorrentes de exigências do legislativo estadunidense); e que ainda há espaço para pesquisas sobre a política comercial estadunidense praticada no período, no que tange à sua interface com os direitos de propriedade intelectual.

Palavras-chave: Acordos Preferenciais de Comércio. Propriedade Intelectual. Comércio. Estados Unidos. América Latina. 


\begin{abstract}
TEODORO, J.P.H. The intellectual property rights of the preferential trade agreements signed by the United States with Latin American countries during the 2000s: motives and normative outcomes. 2015. 65 f. Dissertação (Mestrado) - Instituto de Relações Internacionais, Universidade de São Paulo, São Paulo, 2015.

The article analyzes the intellectual property rights chapters of the preferential trade agreements signed by the United States with Latin American countries during the 2000s, discussing both the country's reasons for signing such agreements (and inserting such discussion in a theoretical framework) and their implications to the intellectual property rights of its signatories. In this regard, it presents some theories about the features intrinsic to the multilateral international institutions, when contrasted with the bilateral and regional ones; such theories claim that states, when dealing with undesired effects of institutional features, modify institutions (or create new ones), in accordance with their objectives. Then, the article presents the findings of a literature review about the U.S. reasons for signing the aforementioned preferential trade agreements, emphasizing those reasons related to intellectual property rights; such findings are complemented by the analysis of the pertinent primary documents. Finally, it compares the content of the chapters with each other; it also compares them with the WTO TRIPS Agreement. It concludes that the U.S. reasons presented coincide with the theoretical expectations; that the analyzed chapters are substantially different from the TRIPS Agreement; that the chapters have many differences with each other (which are, in part, due to U.S. Congress requirements); and that there is still room for new researches on the U.S. trade policy practiced during the analyzed period, when it comes to its interface with intellectual property rights.
\end{abstract}

Keywords: Preferential Trade Agreements. Intellectual Property. Trade. United States. Latin America. 


\section{SUMÁRIO}

1 INTRODUÇÃO

2 ACORDOS MULTILATERAIS VERSUS ACORDOS PREFERENCIAIS: ASPECTOS TEÓRICOS

3 MOTIVAÇÕES ESTADUNIDENSES PARA A ASSINATURA DE MÚLTIPLOS ACORDOS PREFERENCIAIS DE COMÉRCIO NA DÉCADA DE 2000 (COM SEUS RESPECTIVOS CAPÍTULOS SOBRE PROPRIEDADE INTELECTUAL)

4 ANÁLISE COMPARATIVA ENTRE OS CAPÍTULOS SOBRE PROPRIEDADE INTELECTUAL DOS ACORDOS PREFERENCIAIS DE COMÉRCIO FIRMADOS PELOS ESTADOS UNIDOS COM PAÍSES LATINO-AMERICANOS NA DÉCADA DE 2000. 40

4.1 Assinatura de terceiros acordos sobre propriedade intelectual............................................... 40

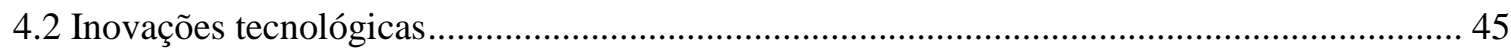

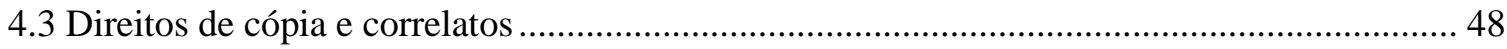

4.4 Especificações sobre produtos químicos para a agricultura e farmacêuticos ........................... 49

4.5 Compromisso com a "Declaração sobre o Acordo TRIPS e Saúde Pública" ........................... 51

4.6 Recursos genéticos e conhecimentos tradicionais.................................................................... 51

4.7 Provisões sobre o cumprimento dos capítulos sobre propriedade intelectual ......................... 52

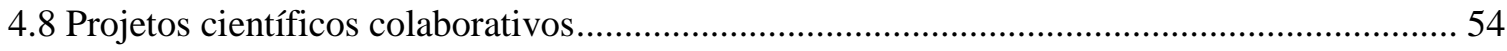

4.9 Provisões sobre patentes e resultados das exigências parlamentares estadunidenses de 200755

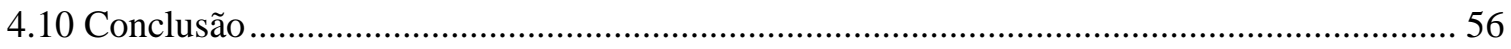

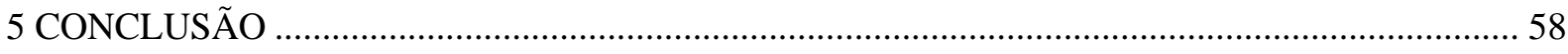

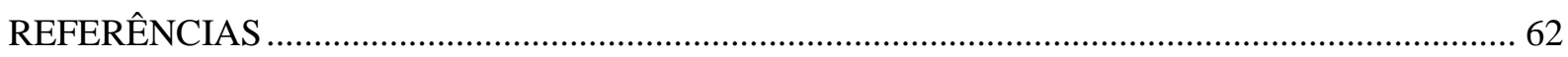




\section{INTRODUÇÃO}

Os direitos de propriedade intelectual presentes nos acordos preferenciais de comércio firmados pelos Estados Unidos com países da América Latina desde a entrada em vigor da Organização Mundial do Comércio (em 1995) até o final da década de 2000 são o objeto principal deste artigo $^{2}$. No total, atualmente, os Estados Unidos têm 14 acordos preferenciais de comércio em vigor para si, dentre os quais doze foram firmados após a entrada em vigor da Organização (e todos esses doze foram firmados na década de 2000). Dentre os 12, o único que não foi negociado durante as presidências de Bush foi o que tem a Jordânia como contraparte (ele foi negociado durante a presidência do democrata William Jefferson Clinton).

A região do mundo que mais reúne países que firmaram acordos de comércio com os Estados Unidos após a entrada em vigor da Organização Mundial do Comércio (OMC) é a América Latina, com dez signatários, daí decorrendo nosso foco de análise nos acordos firmados com países latino-americanos; os negociadores estadunidenses durante os governos de Bush concluíram seus acordos de comércio sob um conjunto de diretrizes parlamentares específico, não aplicável a quaisquer outros acordos de comércio concluídos por seu país (e, conforme veremos, tais orientações influenciaram diretamente o conteúdo dos acordos firmados), excepcionalidade que constitui uma motivação adicional para nosso recorte.

Uma das características comum a todos esses acordos é que, para além de determinar a paulatina liberalização do comércio de bens e serviços entre suas contrapartes, eles contêm capítulos relativamente detalhados sobre direitos de propriedade intelectual.

As negociações e as assinaturas de tais acordos preferenciais se deram apesar da existência da OMC que, em nível multilateral, já determina a seus membros tanto uma ampla redução tarifária quanto a construção de sistemas domésticos de propriedade intelectual. Tal construção é determinada na Organização pelo Acordo TRIPS; o TRIPS, pela primeira vez na história, vinculou os direitos de propriedade intelectual ao comércio em nível internacional. Esse contexto suscita as perguntas: se já havia, em nível multilateral, um vínculo jurídico entre o comércio e a propriedade intelectual, por que os Estados Unidos negociaram com países latino-americanos tantos acordos preferenciais de comércio contendo capítulos sobre propriedade intelectual na década de 2000, quando a OMC já estava em vigor? Como tal escolha pode ser teoricamente explicada? Quais as características de tais capítulos, quando

\footnotetext{
2 Tendo em vista que o conceito de "acordos preferenciais de comércio" inclui também os acordos que contêm mais de duas contrapartes, optamos por utilizá-lo, ao invés de nos referirmos a acordos "bilaterais" de comércio (haja vista a que um dos acordos que analisaremos, o CAFTA-DR, reúne seis contrapartes aos Estados Unidos).
} 
contrastados com o Acordo TRIPS? Tais capítulos são idênticos, ou têm diferenças significativas entre si? Responder a essas perguntas é o objetivo deste artigo.

Nesse sentido, apresentaremos algumas proposições teóricas acerca de acordos preferenciais, em contraste com os multilaterais, que os tornam preferidos pelos estados em determinadas circunstâncias, e revisaremos a literatura sobre os motivos práticos, empíricos, que motivaram os Estados Unidos a firmar diversos acordos preferenciais de comércio com países da América Latina durante a década de 2000, em particular quanto aos motivos relacionados aos direitos de propriedade intelectual (também consultamos alguns documentos oficiais que expressam as diretrizes que os Estados Unidos adotaram ao negociar seus acordos de comércio no período mencionado). Por fim, compararemos os capítulos sobre propriedade intelectual dos acordos de comércio firmados pelos Estados Unidos com países da América Latina na década de 2000, de modo a evidenciar tanto o modo como se diferenciam do Acordo TRIPS quanto em quais aspectos são diferentes entre si, e discutir algumas de suas implicações para seus signatários. Assim, tal análise comparativa evidenciará o resultado normativo dos processos políticos analisados previamente.

\section{ACORDOS MULTILATERAIS VERSUS ACORDOS PREFERENCIAIS: ASPECTOS TEÓRICOS}

Esta seção é eminentemente teórica. Aqui evidenciamos alguns pressupostos acerca da preferência estatal por acordos contendo um número restrito de participantes, ao invés de acordos multilaterais (dos quais participam todos, ou quase todos, os estados envolvidos em determinado problema). Dada as características intrínsecas a cada um desses modos de cooperação, os estados devem optar por criar, modificar e participar de instituições levando em consideração seu formato.

Um pressuposto comum às teorias que descreveremos ao longo da seção 2 é o de que as instituições internacionais importam (de outra forma, não faria sentido que discutissem as implicações das características das mesmas). Dois grandes grupos podem ser discernidos entre os teóricos de Relações Internacionais quanto a esse pressuposto: o primeiro deles afirma que as instituições internacionais ${ }^{3}$ têm pouca ou nenhuma relevância para as relações

\footnotetext{
Em geral, o emprego do termo "instituição" nas teorias de Relações Internacionais não se restringe às organizações internacionais, mas incluem outras formas de mediação das interações estatais, incluindo o direito internacional, tanto o positivado quanto o costumeiro. Assim, os tratados bilaterais ou regionais, mesmo que não dotados de um aparato organizacional (uma sede, funcionários, órgãos ativos, etc.) normalmente estão incluídos no conceito de "instituição".
} 
internacionais uma vez que, em última instância, elas são apenas reflexos do poder dos estados, e, caso haja divergência de interesse entre eles, somente a aplicação de seu poder (e não a mediação de instituições) pode solucionar suas disputas.

Por outro lado, outro grupo afirma que as instituições são importantes por melhorarem a comunicação entre os estados, permitirem a troca de informações entre eles, sintetizarem as informações intercambiadas e ajudarem os estados a superar problemas de ação coletiva através da provisão de um espaço para eles alcançarem decisões e estabelecerem padrões (MARTIN, 1989). Ademais, teóricos desse grupo afirmam que a participação em instituições que coletam e divulgam informações geram custos de reputação (os quais estimulam o cumprimento, pelos estados, de acordos por eles firmados), uma vez que as informações que elas expõem podem influenciar as atividades mesmo dos estados mais poderosos (podendo, inclusive, estimular determinadas reações domésticas) (SNIDAL; KOREMENOS; LIPSON, 2001). Assim, segundo essa interpretação, as instituições reduzem incertezas inerentes às interações internacionais, e os estados as veem como promotoras e mantenedoras da cooperação. Snidal, Koremenos e Lipson (2001), por exemplo, defendem esse argumento, e afirmam que:

\begin{abstract}
A centralização de informações não apenas permite aos estados saber como os outros se comportaram, mas também pode prover interpretações valiosas sobre aquele comportamento. Os estados saberão melhor se a ausência de cooperação dos outros é intencional e merece retaliação ou se é desculpável por causa de circunstâncias extenuantes. Quando os estados retaliam, seus alvos e terceiras partes entenderão melhor a ação como retaliação ao invés de ação não cooperativa unilateral ou erro. Sob a OMC, por exemplo, a retaliação deve ser centralmente autorizada, tornando a má interpretação altamente improvável. (SNIDAL; KOREMENOS; LIPSON, 2001, p. 788, tradução nossa).
\end{abstract}

A afirmação mais ousada dessas teorias (tendo em vista a marcante diferença em relação às proposições realistas) é a de que as instituições influenciam os resultados das interações estatais, constituindo-se, portanto, em uma variável relevante para análises de interações estatais.

O presente artigo se alinha à consideração de que as instituições internacionais são relevantes e, portanto, dignas de atenção acadêmica, e considera que o enorme esforço diplomático do governo dos Estados Unidos na construção de tantos acordos de comércio no período que analisamos é uma evidência da razoabilidade desse posicionamento teórico. 
Um trabalho seminal, que está entre os que consideram as instituições importantes, e que teoriza acerca dos efeitos do formato das instituições internacionais, é o de Snidal, Koremenos e Lipson (2001); eles consideram que:

[...] os estados constroem e modelam instituições para fazer avançar seus objetivos. A implicação mais direta é que diferenças de projeto não são aleatórias. Elas são o resultado de interações racionais e propositais entre estados e outros atores internacionais para resolver problemas específicos. (SNIDAL; KOREMENOS; LIPSON, 2001, p. 762, tradução nossa).

Nesse sentido, Snidal, Koremenos e Lipson (2001) pressupõem que:

1. os estados, a fim de concretizarem seus interesses, projetam instituições para levar adiante interesses que tenham em comum. Nesse processo, os estados levam em conta as informações de que dispõem sobre as preferências alheias e os custos e benefícios associados ao empreendimento institucional; ademais, os atores internacionais são constrangidos por suas "capacidades". A criação, abandono ou modificação de instituições é descrito como um processo interativo:

Esses resultados [alcançados através de instituições] não refletem simplesmente as preferências de atores individuais, mas, ao invés, representam seus esforços conjuntos - e "compromissos" entre suas preferências - para melhorar seu resultado de equilíbrio, dadas as circunstâncias estratégicas com as quais devem lidar. (SNIDAL; KOREMENOS; LIPSON, 2001, p. 781, tradução nossa).

2. o valor dos ganhos futuros deve ser suficientemente forte para dar suporte a arranjos cooperativos: a cooperação só se sustenta quando os estados consideram que os benefícios em se cooperar no longo prazo excedem os custos de se abrir mão de medidas unilaterais, não cooperativas, que atendam a seus interesses imediatos. Snidal, Koremenos e Lipson (2001) consideram, ademais, que a cooperação é sustentável nas relações internacionais contemporâneas, as quais são, segundo eles, caracterizadas pela interdependência, mas que essa propensão a cooperar varia de acordo com a questão.

3. o estabelecimento e a participação em instituições internacionais é custoso: os custos em questão são os relacionados à obtenção de informações sobre o tema da instituição, sobre as preferências alheias e sobre os prováveis efeitos das características da instituição (por exemplo, os estados avaliam o número de atores participantes na mesma).

4. os estados são avessos a riscos e se preocupam com possíveis efeitos adversos decorrentes da criação ou modificação de instituições internacionais: os ganhos obtidos 
devem ser suficientemente grandes, a ponto de compensar a concessão de soberania implicada no envolvimento com instituições internacionais.

Dentre as conjecturas desenvolvidas por Snidal, Koremenos e Lipson (2001) a partir das premissas acima, as seguintes são úteis à explicação de nosso problema:

1. O número de estados participantes é um dos aspectos que os estados tentarão controlar nas instituições: na medida em que o número de participantes em uma instituição aumenta, aumenta também a probabilidade de que não haja incentivos aos atores para que eles contribuam voluntariamente com objetivos comuns aos membros da instituição; desse modo, quando a expectativa dos estados de que o tema a ser regulado é de difícil cumprimento, eles estabelecerão regras estritas de adesão a instituições. Os estados irão, ademais, determinar quais atividades serão realizadas pela instituição com vistas a evitar que se expandam para além do desejado, e também a evitar que ela interfira na sua soberania.

2. Na medida em que aumenta o número de atores participantes em uma instituição, o controle individual de cada ator ou subgrupo de atores diminui; isso acontece porque quando o número de atores é grande, os estados necessitam sacrificar seu controle individual para alcançar benefícios coletivos; quando não há poder de veto e não há possibilidade de modificar uma instituição, a única alternativa restante aos estados insatisfeitos com o status quo é deixar a instituição.

3. Para que uma instituição seja sustentável, a flexibilidade deve aumentar com a severidade dos problemas de distribuição:

Renegotiations of treaty terms, as well as dealing with unilateral invocations of flexibility such as escape clauses, is costly. Moreover, individual states have incentives to free ride on an agreement by developing self-serving interpretations of escape clauses that are broader than intended. And renegotiation provides an opportunity for states to "hold up" the cooperative bargain in an effort to increase their own share. Such incentives become greater as more states are party to an agreement - for the familiar reasons associated with collective action. [...] as more states become involved, modification becomes more difficult and time consuming. (SNIDAL; KOREMENOS; LIPSON, 2001, p. 794). ${ }^{4}$

4 A fim de manter a uniformidade no texto, optamos por traduzir todas as citações provenientes de outros idiomas; as manteremos em seus idiomas originais apenas quando a tradução de conceitos ou expressões acarrete em perda significativa de significado. 
Os autores afirmam, portanto, que instituições mais flexíveis são mais adequadas a situações onde os ganhos gerados não são distribuídos de modo simétrico.

Os autores admitem a possibilidade de que o crescimento de uma instituição gere o quê, na avaliação de seus membros, são problemas; diante desses problemas, eles podem optar por deixar as instituição ou modificá-la, mas ao modificá-la eles devem adequar as características da mesma a seus propósitos. Assim, Snidal, Koremenos e Lipson (2001) afirmam que instituições com características distintas podem oferecer alternativas para solucionar um determinado problema, e que:

\begin{abstract}
Substituições, complementaridades e conflitos emergem não somente no planejamento de instituições individuais, mas também nos relacionamentos entre elas. Assim como características individuais de instituições podem se complementar, também o podem [fazer] diferentes instituições. (SNIDAL; KOREMENOS; LIPSON, 2001, p. 796, tradução nossa).
\end{abstract}

As conjecturas relacionadas ao número de participantes em uma instituição nos são particularmente úteis porque a característica principal, comum aos acordos preferenciais de comércio, é que eles por definição têm número restrito de signatários, ao contrário do regime multilateral. Há diversos trabalhos que, como o de Koremenos, Lipson e Snidal (2001), fazem proposições sobre como o número de participantes em uma instituição influencia no funcionamento da mesma e nos resultados possíveis de se obter através dela; as proposições feitas por alguns desses trabalhos são resumidas ao longo dos próximos parágrafos, onde também apresentamos algumas proposições metodológicas para a determinação de preferências estatais.

Nesse sentido, Frieden (1999) afirma que as preferências de um estado podem ser identificadas através da investigação do comportamento do mesmo; tal identificação é tipicamente feita através do estudo das ações realizadas pelo estado e das ações e pronunciamentos de seus formuladores de política. Contudo, o comportamento observado pode não resultar diretamente da preferência, uma vez que ele pode ser fortemente influenciado pelo ambiente em que se dá; ademais, quando se tenta delimitar a preferência através da análise das posturas dos negociadores durante uma barganha, o resultado obtido poderia ser impreciso, uma vez que:

A posição do representante de um governo [...] tipicamente traz em si cálculos do impacto que essa posição poderia ter. Antecipamos que as 
posições públicas refletem tanto as preferências do ator quanto sua expectativa de como sua postura afetará as ações de outros [atores]. (FRIEDEN, 1999, p. 60, tradução nossa).

Snidal (1985a) considera haver outros obstáculos nessa forma de identificação das preferências: os atores podem abrir mão de seu interesse imediato visando um ganho em longo prazo, de modo que as ações observadas podem não refletir as preferências diretamente; os estados podem ainda abrir mão de ações que seriam individualmente ótimas (individually optimal actions) para cooperar com outros estados para o alcance de resultados mutuamente preferidos; ademais, “[...] somente escolhas de fato feitas por um estado são diretamente observadas; a evidência sobre sua avaliação de outros resultados possíveis é indireta e incompleta.” (SNIDAL, 1985a, p. 41, tradução nossa).

Apesar das mencionadas limitações, a delimitação da preferência de um estado através da observação de seu comportamento pode ser a melhor estratégia de pesquisa disponível em muitos casos. Snidal (1985a) também descreve esse modo de delimitação das preferências, mas considera ser possível que os problemas acima descritos sejam mitigados através da observação da permanência de escolhas idênticas pelos estados ao longo do tempo quando circunstâncias semelhantes se mantêm, ou seja, através da identificação de estabilidade de certo comportamento.

Esse modo de determinação das preferências se foca nas decisões dos formuladores de política dos estados, e propõe ser possível examinar, a partir da análise das práticas internacionais estáveis dos estados, quais são as ações preferidas pelos políticos e pelas burocracias estatais responsáveis pelas políticas externas.

Nesse contexto, quando os estados têm preferências distintas, eles têm que barganhar quando há mais de uma solução possível para um problema internacional. "Mesmo que todas as partes prefiram um conjunto de acordos possíveis à ausência de acordo, elas podem diferir quanto a qual dos acordos possíveis cada uma gosta mais.” (MORROW, 1999, p. 96, tradução nossa). Assim, se instala a dúvida sobre qual é o melhor modo de se cooperar. Snidal, Koremenos e Lipson (2001) resumem esse dilema ao afirmar que: "Se atores preferem resultados diferentes, o intervalo de possibilidades cria problemas de barganha." (SNIDAL; KOREMENOS; LIPSON, 2001, p. 765, tradução nossa).

Os estados têm que decidir se irão cooperar com os demais; uma vez que tenham decidido cooperar, devem ainda decidir como efetuarão tal cooperação, dadas as distintas possibilidades existentes para tanto. Diversos teóricos afirmam que entre as diversas características que os estados têm que observar, ao escolher sobre como cooperar sobre 
determinado tema, está o número de estados envolvidos nas interações, uma vez que tal número pode influenciar no modo como ocorrerão as negociações e no cumprimento de acordos firmados. Essas influências são relevantes quanto à regulamentação das relações comerciais contemporâneas, uma vez que, apesar de já haver uma consolidada organização internacional multilateral dedicada ao vínculo entre comércio e propriedade intelectual, a OMC, os estados membros da Organização podem firmar acordos preferenciais de comércio, e neles incluir normas sobre propriedade intelectual, e eles muito frequentemente o fazem.

Nesse contexto, os estados membros da OMC têm que escolher entre orientar suas relações comerciais unicamente pelo acordo multilateral ou adicionar acordos preferenciais a seus compromissos. Nesse sentido, Snidal (1985b) considera que:

\begin{abstract}
Uma explicação para a variação institucional reside na possibilidade de que diferentes formas de regime possam prover diferentes soluções ao mesmo problema; isto é, dado qualquer problema particular de ação coletiva, uma solução poderia ser alcançada [...] de diferentes modos e ser refletida em desenvolvimentos institucionais correspondentemente diferentes. (SNIDAL, 1985b, p. 923, tradução nossa).
\end{abstract}

Diante dessa possibilidade é que a discussão teórica sobre as características intrínsecas a cada tipo de cooperação se torna relevante.

Nesse sentido, Snidal, Koremenos e Lipson (2001) consideram que o processo de aprendizagem estatal ao longo de repetidas interações, em conjunto com a emergência de novos problemas, são propulsores de mudanças institucionais. Tendo em vista que as interações estatais podem ser permeadas de incerteza, os estados tentam estimar com antecipação as ações dos demais levando em consideração tanto o padrão de ação dos últimos quanto os compromissos por eles assumidos; a acurácia da estimativa baseada nos compromissos é proporcional à credibilidade da contraparte na interação; tal credibilidade é estimada com base no cumprimento dos compromissos e promessas que a contraparte faz, pelo quê um precedente histórico coerente é necessário para que os estados possam estimar as intenções e as ações futuras dos demais. Nesse sentido, Tang (2010) considera que, em um ambiente negociador multilateral, quanto menor o número de estados que negociam ativamente ao longo das rodadas de negociação, maior é a probabilidade de se desenvolverem sinais que indiquem claramente a reputação dos atores, de modo a tornar mais estáveis as futuras interações cooperativas.

Portanto, em função do que foi descrito acima, as ações estatais são escolhidas tanto em função dos objetivos dos estados quanto das interações possíveis com os demais; o 
conjunto de interações estatais quanto a determinado tema determinará, em última instância, os resultados das mesmas e as regras subjacentes a elas.

Nesse sentido, Morrow (1999) considera que o número de atores participantes em uma negociação internacional gera um problema estratégico: "Quanto mais partes há nas negociações, menos provável é a existência de uma zona de acordo entre todas as partes ${ }^{5}$. Ademais, quanto mais partes há nas negociações, mais as negociações são atrasadas simplesmente porque mais posições necessitam ser intercambiadas.” (MORROW, 1999, p. 101, tradução nossa). Uma solução apresentada a esse problema é a redução do número de partes negociadoras, de modo a permitir o alcance de um acordo.

Morrow (1999) especifica como essa redução pode operar em barganhas multilaterais: partes recalcitrantes podem ser excluídas das negociações e do acordo final; ademais, pequenos grupos formados pelas partes mais poderosas podem negociar entre si, e então apresentar seu acordo ao conjunto dos membros que negociam, para obter sua aprovação. Essas técnicas, ainda de acordo com Morrow (1999), aumentam a chance da existência de uma zona de acordo entre as partes ativas e reduzem o tempo necessário para o alcance de um acordo final.

Diante de problemas nas negociações em nível multilateral, a "troca" por acordos que comprometam somente a um número menor de atores é outra solução possível; a impaciência dos estados com a demora que pode existir para se alcançar resultados em negociações multilaterais é um fator explicativo adicional apontado por Morrow (1999) para explicar a opção dos estados por acordos que comprometam somente alguns dos participantes dessas negociações.

Assim, em resumo, para Morrow (1999):

\begin{abstract}
Barganhas multilaterais são tipicamente mais difíceis porque a presença de mais atores reduz a probabilidade de que uma zona de acordo exista. [...] Se os atores estão incertos quanto aos seus níveis de reserva [ou seja, quanto ao intervalo dentro do qual o resultado de uma negociação lhes é aceitável], então outros atores podem persuadi-los através de negociações. (MORROW, 1999, p. 102-103, tradução nossa).
\end{abstract}

Nesse sentido, Kahler (1992) afirma que quando os problemas de ação coletiva verificados

\footnotetext{
Em caso de não haver zona de acordo quanto a uma determinada questão, é possível que tal questão seja vinculada a outras, de importâncias relativas distintas para as partes, de modo que sejam negociadas em conjunto (MORROW, 1999); Snidal, Koremenos e Lipson (2001) desenvolvem argumento semelhante, afirmando que "[...] as the enforcement problem is more severe, the greater the probability of issue linkage." (SNIDAL; KOREMENOS; LIPSON, 2001, p. 787).
} 
em nível multilateral não puderem ser superados, os grandes poderes podem optar por instituições bilaterais ou regionais, as quais são caminhos alternativos que foram persistentemente utilizados no pós Segunda Guerra Mundial.

Snidal, Koremenos e Lipson (2001) enfatizam as dificuldades decorrentes da heterogeneidade de capacidades entre os estados: "Grandes números [de atores barganhando] levanta questões sobre como dividir os custos e benefícios da cooperação, especialmente quando alguns atores são mais ricos, maiores, ou mais poderosos que outros." (SNIDAL; KOREMENOS; LIPSON, 2001, p. 765, tradução nossa), concluindo que “[...] quanto maior o número de atores, mais lentas e mais difíceis [cumbersome, no original] serão as negociações.” (SNIDAL; KOREMENOS; LIPSON, 2001, p. 782, tradução nossa).

No mesmo sentido dos problemas das negociações envolvendo grande número de estados apontados por Morrow (1999), Kahler (1992) e Snidal, Koremenos e Lipson (2001), Tang (2010) considera que o aumento do número de atores em determinada interação aumenta a dificuldade dos mesmos em conhecer as recompensas que cada uma de suas contrapartes obterão (ou seja, o monitoramento mútuo é dificultado). Snidal (1985a) considera que tal aumento resulta em maior complexidade à interação devido às diferenças na distribuição de poder entre os atores.

Dadas as dificuldades intrínsecas às negociações multilaterais descritas acima, Snidal (1985b) conclui que:

\begin{abstract}
Mesmo com um aparato para negociação extensivo e institucionalizado, os estados não são capazes de superar esses problemas facilmente. Portanto, em geral, pode-se esperar que negociações multilaterais envolvendo maiores números de estados aumentem a dificuldade de cooperação. (SNIDAL, 1985 b, p. 929, tradução nossa). ${ }^{6}$
\end{abstract}

Tal como Snidal (1985b), Goldsmith e Posner (2005) também consideram que a cooperação em nível multilateral pode ser particularmente difícil; eles afirmam que acordos firmados nesse âmbito somente podem ter seu cumprimento assegurado através de ações bilaterais dos estados: dada a inexistência de um poder capaz de fazer cumprir acordos internacionais, a punição dos membros de acordos multilaterais que não os cumpram somente pode ser assegurada se os próprios membros dos acordos punirem (individualmente ou em

6 Entretanto, Snidal (1985b) pondera que essa não é uma afirmativa universalmente válida, uma vez que há projetos internacionais que somente são viáveis se contarem com a cooperação de muitos países, de modo que um número maior de países participantes facilita sua consecução. 
grupo) os estados que trapaceiem ${ }^{7}$. Essas considerações são válidas inclusive para o sistema multilateral de comércio: Goldsmith e Posner (2005) consideram que o funcionamento da OMC depende da disposição dos estados de retaliar caso seus parceiros comerciais violem seus compromissos.

O bilateralismo das sanções de comércio implica em que estados fracos não possam se comprometer a sancionar estados poderosos de forma credível, e que estados poderosos em geral terão mais liberdade de ação do que estados mais fracos. (GOLDSMITH; POSNER, 2005, p. 162, tradução nossa).

Nesse sentido,Goldsmith e Posner (2005) afirmam que: “A força do compromisso de um estado com um acordo não é uma função de sua legalidade, mas da força e da uniformidade das preferências públicas e das preferências da elite." (GOLDSMITH; POSNER, 2005, p. 95, tradução nossa) ${ }^{8}$.

Se são pessimistas as conclusões teóricas acerca do multilateralismo de Morrow (1999), Snidal, Koremenos e Lipson (2001), Tang (2010), Snidal (1985b) e Goldsmith e Posner (2005), as quais resumimos nos parágrafos precedentes, o quê explicaria a formação do regime multilateral de comércio do século XX (GATT e OMC)? Goldsmith e Posner (2005) consideram que a principal razão para tanto foi a expectativa dos estados de que o GATT maximizasse os potenciais ganhos do comércio internacional por adotar o princípio de nação mais favorecida, o qual, se esperava, evitaria que acordos bilaterais gerassem desvios de comércio. Essa preocupação se insere no contexto do imediato pós Segunda Guerra Mundial, no qual o GATT foi criado;

Durante a Segunda Guerra Mundial, era senso comum, especialmente no governo dos Estados Unidos, que as guerras de comércio da década de 1930 haviam aprofundado a depressão e contribuído com a ascensão do fascismo e com a eclosão de uma segunda guerra. A convicção de que isso não deveria ocorrer novamente levou ao GATT. Então, desde sue princípios, o GATT esteve marcado por preocupações relativas à segurança. (GOLDSMITH; POSNER, 2005, p. 144, tradução nossa).

7 Snidal, Koremenos e Lipson (2001) estendem esse raciocínio às organizações internacionais; afirmam eles que "Most international organizations have relatively decentralized enforcement arrangements. They specify possible punishments for rule violations but leave it up to the members to apply them." (SNIDAL; KOREMENOS; LIPSON, 2001, p. 772). Eles também citam o Mecanismo de Solução de Controvérsias da OMC como exemplo desse tipo descentralizado de estímulo ao cumprimento de decisões produzidas em instituições internacionais.

8 No caso de acordos de liberalização comercial, Goldsmith e Posner (2005) consideram que diferentes grupos produtivos domésticos podem ter diferentes influências relativas sobre a política comercial praticada por seus estados. 
Outro benefício do sistema multilateral de comércio é o fato de ele ser dotado de infraestrutura administrativa para lidar com disputas entre os estados, e com tribunais que teoricamente proveem resoluções neutras quanto a elas, esclarecem as partes sobre o que constitui ou não violação às regras do GATT/OMC e que desenvolve contínua jurisprudência.

Por fim, o fato de o acordo multilateral gerar uma conveniência aos estados é outra explicação para sua criação:

Todos os estados se beneficiam por encontrar com todos os outros estados durante um período específico, em um lugar específico, ao invés de ter que providenciar um encontro com cada um de suas dezenas de parceiros comerciais. [...] embora coalizões possam se formar e causar problema, os ganhos de se fazer isso parecem pequenos [...]. Em suma, todos os estados têm um interesse em barganhas comerciais multilaterais [...]. (GOLDSMITH; POSNER, 2005, p. 145-146, tradução nossa).

Entretanto, a formação de áreas preferenciais de comércio é uma exceção à regra de nação mais favorecida, e os estados encontraram em tais áreas um modo simples de “contornar" tal fundamento da OMC (GOLSMITH; POSNER, 2005). Goldsmith e Posner (2005) consideram que os estados entram em acordos preferenciais de comércio porque assim eles podem obter concessões comerciais de parceiros importantes sem ter que esperar pela conclusão das rodadas multilaterais de negociação, e porque eles não precisam fazer concessões que beneficiem todos os membros do regime multilateral; consideram eles ainda que os acordos preferenciais frequentemente violam regras do GATT, de modo que a aplicação da regra de não discriminação historicamente falhou ${ }^{9}$.

Assim, apesar dos benefícios supradescritos, o regime multilateral não correspondeu a todas as expectativas de ao menos alguns de seus participantes. Nesse sentido, Tang (2010) considera que o número de estados participantes da OMC resultou em uma heterogeneidade de posições que está tornando "proibitivas" as negociações no âmbito da Organização, de modo que é mais restrito o número de assuntos comerciais sobre os quais todos os estados se dispõem a negociar.

$9 \quad$ Segundo Kahler (1992) essa falha se manifestou desde os princípios do GATT, e ela resulta da preferência dos grandes poderes pela regulamentação bilateral de ao menos parte de suas relações comerciais (o desejo de formação de áreas regionais de livre-comércio (como o Mercado Comum Europeu), a manutenção de vínculos preferenciais de comércio remanescentes do período colonial, e a imposição de cotas a certos produtos provenientes de países em desenvolvimento são os principais motivos mencionados por Kahler (1992) para explicar as exceções ao multilateralismo que se desenvolveram já imediatamente após a criação do GATT). 
[...] o amplo conjunto de temas a serem negociados dentro do mesmo fórum aumentou a complexidade das negociações na OMC, o que ameaça a consistência de quaisquer acordos futuros. [...] o súbito crescimento do sistema da OMC inegavelmente criou muitos efeitos adversos à eficiência e aos métodos de implementação de suas decisões. Ademais, a natureza vinculante desse enorme sistema multilateral constrangeu o intervalo de ação de seus países membros, uma vez que se tornou muito mais difícil para eles renegociar as regras já acordadas ou derrogar delas. (TANG, 2010, p. 140, tradução nossa).

As proposições teóricas sobre a opção dos estados por acordos multilaterais ou por acordos com número mais restrito de participantes que resumimos até aqui foram desenvolvidas no âmbito da Ciência Política, de Relações Internacionais e do Direito Internacional; na literatura produzida pela Economia Política Internacional também há diversas análises dedicadas aos efeitos de acordos de comércio preferenciais e multilaterais. Como exemplo dessas análises podemos mencionar a feita por Bhagwati (1993), que contrasta o multilateralismo ao regionalismo comercial. Nela, Bhaghwati (1993) propõe algumas explicações para a preferência dos países por formar acordos de livre-comércio e uniões aduaneiras. Uma razão propriamente econômica é o uso de áreas de livre-comércio para promover a diversificação produtiva:

[...] dado qualquer nível desejado de industrialização através de substituição de importações, os países em desenvolvimento com seus mercados pequenos poderiam reduzir o custo de tal industrialização ao explorar economias de escala através da abertura preferencial mútua de seus mercados [conforme formularam economistas na década de 1960]. (BHAGWATI, 1993, p. 28, tradução nossa).

Ademais, afirma ele que os burocratas preferem negociar em grupos pequenos, com contrapartes que tenham opiniões parecidas; ainda segundo Bhagwati (1993):

[...] os proponentes do regionalismo tendem a ser melhor focados e mobilizados (eles são frequentemente "experts" regionais e partidários que se aliam eles próprios com as opções políticas preferidas dos países cuja causa de APC [Acordo Preferencial de Comércio] eles apoiam). [...] o regionalismo pode ser apelativo aos políticos, uma vez que ele se transforma mais facilmente em votos [...]. (BHAGWATI, 1993, p. 42, tradução nossa).

Além dos políticos e burocratas, afirma ele que os grupos produtivos privados (business groups) também podem preferir o regionalismo.

Ademais, considera Baghwati (1993), no nível do GATT pode ser mais difícil desacelerar a implementação de reduções tarifárias negociadas, e de se fazer novos compromissos quando as circunstâncias os requeiram, devido ao maior número de membros 
participantes.

O fato de, em negociações de acordos de livre-comércio ou uniões aduaneiras, os países mais fracos poderem aceitar demandas específicas dos estados fortes, mesmo que essas não sejam ótimas do ponto de vista da eficiência econômica do sistema mundial de comércio ou do bem-estar (como são, por exemplo, segundo Bhagwati (1993), as inclusões de normas sobre propriedade intelectual em acordos de comércio) é uma razão adicional apontada por ele para que os estados busquem acordos nesses níveis mais restritos ${ }^{10}$; ademais, essas concessões bilaterais podem se traduzir em apoio a concessões semelhantes em nível multilateral (e, portanto, a negociação de acordos preferenciais de comércio pode ser um instrumento para se atingir determinados resultados em nível multilateral).

As teorias e análises resumidas até aqui evidenciam que há diversos argumentos teóricos que assinalam as deficiências de acordos multilaterais, e que a regulação global do comércio, apesar de ser fundada em um acordo multilateral, não evitou que seus membros buscassem assinar diversos acordos preferenciais.

Os argumentos teóricos descritos ao longo desta seção podem nos ajudar a estimar quais são as expectativas subjacentes à opção dos estados por regulamentar suas relações comerciais através de acordos preferenciais de comércio, apesar de a OMC já existir no âmbito multilateral. Conforme consideramos na introdução, essa opção tem implicações para a proteção à propriedade intelectual, uma vez que os acordos preferenciais de comércio assinados desde 1995 tipicamente têm capítulos sobre propriedade intelectual, tal como a OMC tem o Acordo TRIPS.

Uma vez discutidos os aspectos gerais e teóricos para a opção estatal por acordos preferenciais de comércio, na próxima seção apresentaremos o resultado de um levantamento bibliográfico da literatura acadêmica disponível sobre a preferência dos Estados Unidos na década de 2000 que orientaram o país a firmar seus acordos preferenciais com países da América Latina, os quais tipicamente contêm capítulos sobre propriedade intelectual; os documentos primários oficiais relevantes também foram consultados. Para a verificação de tal preferência, nos baseamos na afirmação de que a observação de comportamentos estatais estáveis permite a dedução da preferência de um estado, conforme proposto Snidal (1985a) e Frieden (1999).

10 Dada essa característica das negociações assimétricas, Bhagwati, Krishna e Panagariya (2014) afirmam que um poder hegemônico como os Estados Unidos obtém mais benefícios ao negociar sequencialmente com um grupo de poderes não hegemônicos do que se o fizesse simultaneamente com um grupo de tais poderes. 
$\mathrm{O}$ modo como as proposições teóricas aqui apresentadas se relacionam às ações estadunidenses sob análise será explicitado na conclusão, presente na seção final do artigo.

\section{MOTIVAÇÕES ESTADUNIDENSES PARA A ASSINATURA DE MÚLTIPLOS ACORDOS PREFERENCIAIS DE COMÉRCIO NA DÉCADA DE 2000 (COM SEUS RESPECTIVOS CAPÍTULOS SOBRE PROPRIEDADE INTELECTUAL)}

A revisão bibliográfica aqui apresentada decorreu de busca realizada no JSTOR no dia 27 de outubro de 2014 de artigos publicados entre 01/01/2000 e 27/10/2014; os termos utilizados para a busca foram "United States", "trade", "investment" e "intellectual property", na base "International Relations". Uma busca com os mesmos termos foi realizada no "Portal CAPES" no dia 18 de janeiro de 2015, incluindo trabalhos publicados entre 01/01/2000 e 18/01/2015. Trabalhos presentes nas bibliografias desses artigos originalmente coletados, e trabalhos de especialistas no tema (incluindo livros) foram também consultados.

A responsabilidade pela negociação de acordos de comércio pelos Estados Unidos cabe ao Office of the United States Trade Representative (USTR, em sua sigla em inglês; Escritório do Representante de Comércio dos Estados Unidos, em tradução livre para o Português $)^{11}$, mas cabe ao presidente do país decidir se assina os mesmos; para que os acordos internacionais entrem em vigor para os Estados Unidos, devem contar com a aprovação de ao menos dois terços dos membros do Senado (UNITED STATES SENATE, 2015).

A fim de agilizar a conclusão de acordos de comércio, o Congresso ${ }^{12}$ pode realizar um acordo com o presidente (chamado "Trade Promotion Authority Act"), no qual o legislativo se compromete a debater a ratificação de acordos em no máximo noventa dias após a submissão para sua avaliação (esse mecanismo é conhecido como "fast track", e é comumente assim referenciado na literatura) (BECKER; BLAAS, 2007) ${ }^{13}$. Quando um acordo é

11 O USTR é responsável por desenvolver e coordenar a implementação de tratados internacionais nos Estados Unidos (ALBERTSON, 2010); tem, ademais, a função de monitorar o cumprimento de acordos de comércio pelas suas contrapartes (podendo, ainda, recomendar ao presidente que ele retire benefícios que foram concedidos a outros países através de acordos de comércio, ou que imponha tarifas a bens originados de países que violem o que o USTR identifique como sendo os interesses estadunidenses relacionados à propriedade intelectual (SELL, 2003); o chefe desse escritório é o representante oficial de comércio dos Estados Unidos, o qual é escolhido pelo presidente. Durante as presidências de Bush, tais representantes foram Robert Zoellick (entre 2001 e 2005), Robert Portman (entre 2005 e 2006) e Susan Schwab (entre 2006 e 2008).

12 O legislativo estadunidense é bicameral, sendo composto pelo Senado e pela "House of Representatives". O emprego do termo "Congresso", tanto na literatura acadêmica quanto nas publicações oficiais, se refere a ações conjuntas entre ambos os componentes do legislativo.

13 Nos Estados Unidos, o Congresso tem o dever constitucional de regular o comércio com nações estrangeiras (ALBERTSON, 2010). Assim, embora formalmente caiba apenas ao Senado ratificar tratados, "[...] um 
negociado sob o "fast track", ademais, é necessária a aprovação de ambas as casas do legislativo com uma maioria simples em cada (LANTIS, 2005). Uma vez que o legislativo tenha dado o aval, o presidente deve decidir se incorpora o Acordo ao ordenamento jurídico doméstico (BENTES et. al., 2008).

Bush obteve um "fast track" em janeiro de 2002; nele, o Congresso afirma que os acordos de comércio maximizam as oportunidades decorrentes da propriedade intelectual, e que ela está entre os "setores críticos" e "blocos construtores" da economia dos Estados Unidos (UNITED STATES SENATE; THE HOUSE OF REPRESENTATIVES OF THE UNITED STATES OF AMERICA, 2002, p. 61). A validade original do fast track conferido a Bush era até primeiro de junho de 2005, podendo o presidente solicitar ao Congresso a extensão dessa validade para até primeiro de julho de 2007; Bush solicitou tal extensão e a obteve.

Na Trade Promotion Authority Act de 2002 o Congresso determinou alguns objetivos de negociação específicos, relativos à propriedade intelectual: a implementação do Acordo TRIPS por suas contrapartes; a proteção de novas tecnologias (citando inclusive os métodos de distribuição e transmissão de produtos protegidos por direitos de propriedade intelectual); a garantia de que as provisões sobre propriedade intelectual dos acordos de comércio reflitam um nível de proteção a tais direitos similar ao verificado nos Estados Unidos; o respeito à "Declaração sobre o Acordo TRIPS e Saúde Pública"14; e a garantia do provimento de "[...] strong enforcement of intellectual property rights, including through accessible, expeditious, and effective civil, administrative, and criminal enforcement mechanisms [...]." (UNITED STATES SENATE; THE HOUSE OF REPRESENTATIVES OF THE UNITED STATES OF AMERICA, 2002, p. 64).

O fast track de 2002 determinou ainda o intercâmbio de informações entre o USTR e o Congressional Oversight Group, o qual é composto por ao menos quatro deputados e quatro senadores, e que é necessariamente bipartidário. Ademais, cada membro do Congressional Oversight Group:

[...] deve ser acreditado pelo Escritório do Representante de Comércio dos Estados Unidos em nome do presidente como um conselheiro à delegação dos Estados Unidos nas negociações [...]. O Congressional Oversight Group deve se consultar com o Representante de Comércio (e a ele prover conselhos) quanto à formulação de objetivos específicos, estratégias de

tratado aprovado somente pelo Senado oferece um mecanismo imperfeito de consideração de acordos de comércio." (MASTEL; SHAPIRO, 2006, p. 52, tradução nossa).

14 Sobre essa Declaração e seu contexto, cf. seção 3, abaixo. 
negociação e de posições, ao desenvolvimento de acordos de comércio aplicáveis, e ao compliance e enforcement de compromissos negociados sob o acordo de comércio. (UNITED STATES SENATE; THE HOUSE OF REPRESENTATIVES OF THE UNITED STATES OF AMERICA, 2002, p. 85 , tradução nossa). ${ }^{15}$

Antes de iniciar qualquer negociação sob os auspícios do fast track, o presidente deve, ademais, se consultar com os comitês legislativos dedicados ao comércio e com qualquer comitê legislativo sobre temas que venham a ser negociados.

Mastel (2012) afirma que o fast track conferido a Bush de fato influenciou no texto final dos acordos preferenciais de comércio assinados por esse presidente:

[...] o presidente de fato tem alguma liberdade para interpretar os objetivos [definidos pelo Congresso no fast track], mas seria difícil argumentar que as direções do Congresso quanto a direitos trabalhistas e questões ambientais e para proteger a integridade das leis antidumping e da lei de impostos de contramedida [countervailing duty law no original] não tiveram um impacto nos acordos de comércio dos Estados Unidos. As diretivas congressionais também ajudaram a dar forma à postura dos Estados Unidos em questões mais novas como propriedade intelectual, investimento e serviços. (MASTEL, 2012, tradução nossa).

Em maio de 2007, os membros do Congresso chegaram a um entendimento formal com o executivo quanto a vários pontos em negociação nos acordos de comércio. Tal entendimento foi necessário para que os acordos de comércio cujas ratificações estavam pendentes (Peru e Colômbia) fossem apreciados, e ele decorreu da nova maioria de democratas no Congresso, resultada da eleição de 2006; as novas determinações parlamentares se aplicaram também ao acordo com o Panamá e com a Coreia do Sul, cujas negociações ainda não estavam concluídas. Os democratas exigiam mudanças no escopo dos acordos quanto a padrões trabalhistas e ambientais. Eles demandavam também a inclusão de provisões sobre saúde pública e acesso a medicamentos, temas tradicionalmente associados às patentes. $\mathrm{O}$ entendimento entre o Congresso de maioria democrata e a presidência republicana resultou em mudanças nos acordos com o Peru, a Colômbia, o Panamá e a Coreia do Sul (ou

15 Sem o fast track, a comunicação entre o USTR e o Congresso não é tão próxima, o que torna mais difícil o processo negociador (conforme afirma Schwab in $\mathrm{Wu}, 2013$ ). Schwab afirma, ademais, que a consulta entre os negociadores do USTR e atores privados é considerada fundamental pelos primeiros durante a negociação de acordos de comércio; a literatura afirma haver uma relação entre os capítulos sobre propriedade intelectual que estudamos e interesses privados específicos, conforme detalharemos abaixo. 
seja, nos acordos preferenciais de comércio firmados pelos Estados Unidos desde 2006), inclusive quanto aos direitos de propriedade intelectual (BENTES et. al., 2008). ${ }^{16}$

$\mathrm{O}$ entendimento entre o Congresso e a presidência afirmou que os acordos de comércio deveriam ter um nível "forte" de proteção a direitos de propriedade intelectual, mas que eles poderiam ter certas "flexibilidades" quanto ao tema:

Within this overall framework of strong intellectual property protection, the agreement reached with the Congressional leadership aims to incorporate certain flexibilities. These modifications are aimed at further ensuring that developing country free trade agreement partners are able to achieve an appropriate balance between fostering innovation in, and promoting access to, life-saving medicines. (OFFICE OF THE UNITED STATES TRADE REPRESENTATIVE, 2007a, p. 3).

Ademais, nesse entendimento, foram estabelecidas as seguintes diretrizes específicas relacionadas à propriedade intelectual:

- o período de proteção de dados submetidos para a aprovação de medicamentos nos países em desenvolvimento "geralmente" não deveria se estender para além do período de proteção para o mesmo produto nos Estados Unidos, e as contrapartes em acordos de comércio deveriam ser "encorajadas" a processar rapidamente pedidos de aprovação para comercialização de novos medicamentos.

- o documento determina que os países em desenvolvimento membros de acordos preferenciais de comércio com os Estados Unidos poderiam implementar exceções a regras normais de proteção a dados de testes caso isso fosse necessário para proteger a saúde pública.

- os acordos preferenciais de comércio com países em desenvolvimento deveriam ter uma abordagem mais flexível quanto à adição ao tempo de validade de uma patente por conta de atrasos na concessão da mesma; entretanto, todas as contrapartes em acordos preferenciais de comércio deveriam fazer seus melhores esforços para rapidamente processar pedidos de patente e pedidos de aprovação para comercialização.

- os acordos preferenciais de comércio deveriam prover às suas contrapartes em desenvolvimento maior flexibilidade quanto aos tipos de procedimento permitidos para evitar a comercialização de produtos infratores de patentes.

16 Segundo Bentes et. al. (2008), o acordo com o Peru foi emendado em 24 e 25 de junho de 2007, e o acordo com a Colômbia o foi em 28 de junho de 2007. O acordo com o Panamá e o acordo com a Coreia do Sul foram finalizados já em concordância com as mudanças demandadas pelo Congresso. 
- deveria haver um compromisso formal entre as partes dos acordos preferenciais de comércio afirmando o mútuo comprometimento com a "Declaração sobre o Acordo TRIPS e Saúde Pública" (enquanto a diretriz parlamentar original, de 2002, apenas exigia o "respeito" à Declaração, sem ditar a necessidade da formalização nos acordos de comércio de um compromisso quanto a esse tema).

Quando, através dos processos que descrevemos acima, os poderes legislativo e executivo dos Estados Unidos têm consolidada a intenção de negociar, assinar e ratificar acordos preferenciais de comércio, resta aos negociadores estadunidenses escolher quais países serão abordados para tanto. Segundo Schott (2004), ao escolher os parceiros com os quais negociar acordos de comércio, o USTR observa as seguintes variáveis:

- estimativa quanto ao apoio parlamentar: o USTR estima se um acordo com determinado país será aceitável aos parlamentares estadunidenses ou se, ao contrário, alguma provisão do acordo irá dificultar a ratificação (por exemplo, compromissos em setores produtivos sensíveis como a agricultura e a indústria de têxteis provavelmente encontrarão resistência no legislativo e, portanto, países que provavelmente façam exigências quanto a esses produtos (que sejam estritas a ponto de colocar em risco a conclusão da negociação de acordos de comércio) não são vistos como bons parceiros pelo USTR).

- nível de comprometimento da contraparte: tendo em vista que muitas das provisões dos acordos preferenciais dos Estados Unidos requerem significativas reformas das práticas regulatórias de suas contrapartes, o USTR estima a disposição e a habilidade dos países em modificar suas políticas para atender às exigências de um pacto de livre-comércio.

- considerações de política externa: o apoio internacional aos Estados Unidos em outras áreas, que não o comércio, é considerado pelo USTR ao eleger os países para os quais proporá acordos de comércio; o autor afirma que o bom andamento verificado nas negociações com a Austrália em parte se deveu ao apoio desse país à guerra no Iraque, e que as negociações com o Bahrain recompensavam esse país pérsico porque, no entendimento de Washington, ele promovia a reforma democrática e a paz na sua região. Outro objetivo amplo de política externa que segundo Schott (2004) orientaria a escolha estadunidense é a representatividade regional: o país teria iniciado negociações com países em diversas regiões (como a América Latina, o Oriente Médio e o nordeste asiático) na expectativa de estabelecer “[...] blocos construtores que ao longo do tempo podem resultar em pactos regionais mais amplos." (SCHOTT, 2004, p. 370, tradução nossa). Os acordos assinados com Marrocos e Bahrain (em conjunto com o que Clinton negociara com a Jordânia) eram, segundo o autor, vistos por 
Washington como antecedentes da criação de um único acordo de comércio que envolvesse vários países do oriente médio.

Através do fast track obtido em 2002 (e sua respectiva extensão), Bush concluiu a negociação dos acordos de comércio com Cingapura e Chile (em 2003), Austrália, Bahrain, Marrocos e o CAFTA-DR (em 2004) ${ }^{17}$; Omã, Peru e Colômbia (em 2006); e Coreia do Sul e Panamá (em 2007), e os submeteu para ratificação ${ }^{18}$.

Abaixo enumeramos as razões pelas quais, de acordo com a literatura consultada, os Estados Unidos optaram por firmar tais acordos preferenciais de comércio contendo capítulos sobre propriedade intelectual:

1 Dificuldades em âmbito multilateral: diversos pesquisadores consideram que a negociação de acordos preferenciais foi vista pelos Estados Unidos como um método para contrabalancear o quê, na avaliação da diplomacia do país, eram perdas em nível multilateral.

Chorev (2007), por exemplo, afirma que os Estados Unidos, no início da Rodada Doha de negociações da OMC, queria evitar compromissos sobre reduções de subsídios agrícolas, avançar negociações sobre investimentos e ao menos manter o status quo dos direitos de propriedade intelectual presentes no Acordo TRIPS. Entretanto, houve intensa diferença entre as propostas e intenções dos Estados Unidos e as de muitos países em desenvolvimento.

Quanto à propriedade intelectual, um documento que assinala as diferenças de posição entre os Estados Unidos e muitos outros membros da OMC é a "Declaração sobre o Acordo TRIPS e saúde pública"; ela resultou de negociações originalmente requisitadas por um grupo de 20 países em desenvolvimento; nela, os membros da OMC esclarecem que caberia a cada país declarar-se, quando julgasse necessário, estar sob emergência de saúde pública, o que os permitiria emitir licenças compulsórias às patentes dos medicamentos necessários para superar essa situação ${ }^{19}$. Ademais, a Declaração estabeleceu que até $1^{\circ}$ de janeiro de 2016 os membros "menos desenvolvidos" da OMC não estão obrigados, no que se refere ao

17 O CAFTA-DR reúne seis contrapartes aos Estados Unidos: Costa Rica, El Salvador, Guatemala, Honduras, Nicarágua e República Dominicana. A República Dominicana foi o último signatário a aderir ao acordo, e o fez na fase de revisão jurídica e de redação do tratado, quando as negociações entre os Estados Unidos e os membros continentais já haviam terminado (DÍAZ, 2008, p. 102).

18 Dentre esses, todos foram aprovados pelo legislativo ainda durante a gestão de Bush, com exceção do acordo com a Colômbia e do acordo com o Panamá, ambos ratificados em outubro de 2011.

19 A "licença compulsória" pode ser definida como "[...] a autorização dada por uma autoridade judiciária ou administrativa a um terceiro para uso de uma invenção patenteada, sem o consentimento do patenteador, com base em vários elementos de interesse geral (por exemplo: ausência de trabalho, saúde pública, práticas anticompetitivas, emergência, defesa nacional).”(CORREA, 2005, p. 29). 
patenteamento de produtos farmacêuticos, a implementar ou aplicar as disposições do Acordo TRIPS, e determinou um prazo para que os membros da OMC definissem uma solução técnica para que os países com capacidade de produção farmacêutica insuficiente também pudessem se beneficiar da emissão de licenças compulsórias (WORLD TRADE ORGANIZATION, 2001). Tal solução foi definida em agosto de 2003 (WORLD TRADE ORGANIZATION, 2003). O texto final desses acordos, conforme estudos sobre as negociações dos mesmos indicam, é muito mais próximo das propostas dos países em desenvolvimento do que das propostas feitas pelos Estados Unidos, as quais são, em muitos aspectos, contrárias às propostas dos primeiros.

Apesar desses revezes para os Estados Unidos, em junho de 2002, em negociações realizadas no Conselho do TRIPS $^{20}$, países com expressiva produção farmacêutica, entre os quais estavam os Estados Unidos, rejeitaram com sucesso uma demanda de alguns países em desenvolvimento, que queriam obter um dispensa temporária da aplicação de "mailbox", presente no Acordo TRIPS ${ }^{21}$.

Quando um determinado pedido de patente tenha sido incluído no mencionado dispositivo, o solicitante deve ter um período de exclusividade de comercialização do produto a ele concernente válido até cinco anos após a obtenção da autorização para comercialização (a menos que a concessão ou rejeição da patente seja determinada, e desde que uma patente tenha sido concedida ao mesmo produto em outro membro da OMC), e o solicitante tem seu tempo de patente considerado desde a data em que a inclusão na mailbox foi feita.

Nesse contexto, na avaliação de Chorev (2007), os direitos de propriedade intelectual estiveram entre os temas mais controversos das negociações iniciais da Rodada Doha, junto com os subsídios agrícolas e as questões de Cingapura (compras governamentais, investimentos, truste e facilitação do comércio).

Outra explicação encontrada na literatura para que as dificuldades verificadas nas negociações da Rodada Doha da OMC é o desinteresse dos atores privados na Organização, em contraste com sua participação ativa, através de seus governos, na criação da OMC; nesse

20 O Conselho do TRIPS, composto por representantes dos membros da OMC, tem por função monitorar a aplicação do Acordo TRIPS e permitir consultas entre eles sobre temas relacionados ao Acordo.

21 “A provisão mailbox, encontrada no artigo 70.8 do Acordo TRIPS, requer que aqueles membros que não tinham regras para a proteção por patentes [de produtos farmacêuticos ou produtos químicos para a agricultura] até janeiro de 1995 passassem a ter um sistema de mailbox através do qual inventores possam arquivar solicitações de proteção por patente. O objetivo do sistema é proteger os direitos dos inventores que arquivaram primeiro, ainda que suas aplicações não sejam abertas e revisadas até que um sistema de leis sobre patentes próprio seja proclamado." (INTELLECTUAL PROPERTY \& TECHONOLOGY LAW JOURNAL, 2003, p. 21, tradução nossa). 
sentido, Cesar e Sato (2012) argumentam que o desinteresse das empresas no sistema multilateral de comércio decorre do fato de ele não ser mais adequado ao atual estágio de produção, caracterizado pela intensificação da dispersão geográfica, realizada agora através de cadeias de valor globais (enquanto as regras da OMC e as discussões de Doha, por serem pautadas somente no comércio de bens acabados, não contemplam essa realidade, consideram os mencionados autores).

Até o final da década de 2000, a rodada de negociações iniciada em Doha permanecia em um impasse. Embora no fast track de 2002 o Congresso dos Estados Unidos tenha estabelecido que os negociadores do país deveriam se esforçar para concluir as negociações na OMC até primeiro de janeiro de 2005, as divergências internacionais supradescritas impossibilitaram o alcance de tal objetivo.

As dificuldades relacionadas à propriedade intelectual que mencionamos nos parágrafos precedentes, segundo Chorev (2007) motivaram os Estados Unidos a tentar minar, nos acordos preferenciais, as flexibilidades reconhecidas na "Declaração sobre o Acordo TRIPS e Saúde Pública" e em seu subsequente desenvolvimento de 2003. Em suma, para Chorev (2007) as motivações dos Estados Unidos subjacentes às provisões sobre propriedade intelectual de todos os acordos preferenciais que firmaram após a entrada em vigor do Acordo TRIPS foram:

[...] to limit potential exclusions from patentability [...], require the grant of patents for "new uses" of known compounds, require patent term extension under certain conditions [...], prevent parallel importation ${ }^{22}$, limit the grounds under which compulsory licenses may be granted [...], and allow for the prosecution of non-violation nullification of impairment claims. (CHOREV, 2007, p. 47).

Chorev (2007) afirma que, em face dessas dificuldades em nível multilateral, o impasse verificado nas negociações ministeriais de Cancun em 2003 foi um marco no direcionamento estadunidense aos acordos preferenciais de comércio. Ela cita indiretamente, em suporte a essa afirmação, Robert Zoellick, que afirmara que “[...] os Estados Unidos iriam buscar alternativas institucionais à multilateral para alcançar aqueles objetivos não alcançados

22 A parallel importation (traduzida ao Português como "importação paralela") ocorre quando um determinado país permite a importação de um bem patenteado sem a necessidade de consentimento do detentor do direito de patente correspondente; nesse caso, o país importador adota um regime de esgotamento internacional de direitos de patente. A consecução dessa importação depende de um regime de esgotamento equivalente no país exportador (NOEHRENBERG, 2006, p. 171). Isso permite, por exemplo, que medicamentos produzidos sob patentes sejam adquiridos no mercado internacional pelo menor preço disponível (ABBOTT, 2002, p. 497). Os Estados Unidos estão entre os países que adotam o regime contrário ao descrito, ou seja, lá é adotado um regime nacional de esgotamento de direitos de propriedade intelectual (SELL, 2007). 
na OMC.” (CHOREV, 2007, p. 34-35, tradução nossa). Schott (2004), também citando Zoellick, afirma que as negociações comerciais em nível bilateral e regional eram vistas como construtoras de alternativas para caso as negociações da Rodada Doha paralisassem por completo.

Outra representante do USTR que manifestou publicamente sua interpretação de que somente o sistema multilateral era insuficiente para a regulamentação satisfatória do comércio foi Susan Schwab; em um seminário realizado em 6 de abril de 2013 (quando ela já não era mais a chefe do USTR), Schwab afirmou que um ponto positivo dos acordos preferenciais é que eles podem lançar precedentes em questões que podem posteriormente ser levadas com sucesso para o sistema multilateral de comércio, e que a Rodada Uruguai é ultrapassada devido aos avanços verificados no comércio e nos investimentos (ela exemplifica esse anacronismo que considera haver nos fundamentos da $\mathrm{OMC}$ afirmando que "A última grande negociação sob os auspícios da OMC, o Acordo sobre Tecnologias da Informação, foi em meados da década de 1990." (Schwab in WU, M. et. al., 2013, p. 457, tradução nossa).

Outra dificuldade relacionada à propriedade intelectual que os Estados Unidos enfrentaram na $\mathrm{OMC}$ diz respeito às normas sobre a apreensão de bens em trânsito ${ }^{23}$ suspeitos de violarem direitos de propriedade intelectual; de acordo com o artigo 51 do Acordo TRIPS, o detentor de um direito de propriedade intelectual pode solicitar às autoridades de um país que suspendam a importação de bens que infrinjam seus direitos de propriedade intelectual (GENERAL AGREEMENT ON TARIFFS AND TRADE, 1994); entretanto, cada signatário deveria decidir sobre a extensão dessa medida aos bens em trânsito (CORREA, 2008); o artigo 51 tampouco limita a discricionariedade que cada país tem para apreender ou não bens destinados a importações paralelas que estejam em trânsito. Os Estados Unidos (bem como o Japão e a Suíça) apoiaram uma proposta feita pela União Europeia ao Conselho do TRIPS em 2005 para que o artigo 51 do Acordo fosse emendado, de modo que seu escopo de aplicação necessariamente se estendesse a bens em trânsito.

Entretanto, a questão foi contestada por países em desenvolvimento [...], e no encontro do Conselho em junho de 2008 a questão não foi apresentada novamente por esses membros [que originalmente a haviam apresentado] (e tampouco foi incluída na agenda de Doha); os países em desenvolvimento ressaltaram sua necessidade de se beneficiar dos direitos de propriedade intelectual e de se aproveitarem das flexibilidades do TRIPS. (MICARA, 2012 , p. 89 , tradução nossa).

${ }^{23}$ Os bens "em trânsito" em determinado território são aqueles que não são exportados ou importados a partir desse território, mas que lá passam por procedimentos de fiscalização enquanto seguem para outro território. 
Correa (2008) descreve outra proposta da União Europeia na OMC que contou com apoio dos Estados Unidos mas que, igualmente, encontrou resistência de outros países:

Em outubro de 2005, as Comunidades Europeias e seus estados membros propuseram que o Conselho do TRIPS revisasse a aplicação efetiva [enforcement, no original] das obrigações decorrentes do TRIPS para estabelecer meios de ajudar na luta contra os problemas relacionados à pirataria e à contrafação ${ }^{24}$. Enquanto vários países desenvolvidos como os Estados Unidos e o Japão mostraram apoio geral a essa proposta, muitos países em desenvolvimento manifestaram forte oposição. (CORREA, 2008, p. 37, tradução nossa).

Em face dessas diferenças com países em desenvolvimento relacionadas à propriedade intelectual no âmbito da OMC, onde o costume de se tomar de decisões por consenso permite que grupos de países em desenvolvimento se unam para bloquear o avanço de certas propostas dos países desenvolvidos (ou, ainda, que somem forças para avançar discussões e resoluções que queiram), os Estados Unidos, segundo Deere (2009), optaram pela negociação de acordos preferenciais porque assim evitariam a ação coletiva de países em desenvolvimento.

Embora as dificuldades descritas até aqui digam respeito a diferenças dos Estados Unidos com países em desenvolvimento, tampouco houve concordância entre os países desenvolvidos quanto a alguns aspectos dos direitos de propriedade intelectual: após a entrada em vigor do Acordo TRIPS, não houve concordância entre a União Europeia e os Estados Unidos quanto à maior especificação dos bens a serem protegidos por indicações geográficas; o Canadá defendeu algumas flexibilidades do Acordo TRIPS, contrariamente aos demais países desenvolvidos (DEERE, 2009).

Nesse sentido, Muzaka (2011) afirma que através da intensificação de assinatura de acordos preferenciais após 2003 os Estados Unidos almejavam aprofundar a liberalização comercial com os países interessados em aceitar suas exigências para tanto, deixando para trás os países indispostos a prosseguir com essa tarefa (a autora também cita indiretamente Zoellick em suporte a essa afirmação).

Assim, segundo essa linha de interpretação, a negociação de acordos preferenciais foi vista por Washington como uma forma de superar as dificuldades verificadas em nível

${ }^{24} \mathrm{Na}$ literatura, o termo "pirataria" normalmente se refere à produção e distribuição ilegal de bens protegidos por direitos de cópia e seus correlatos; o termo "contrafação" se aplica aos demais modos de proteção à propriedade intelectual, notadamente às patentes. Sobre a distinção entre direitos de cópia e correlatos, cf. seção 4.3. 
multilateral, entre as quais estão as relativas aos direitos de propriedade intelectual; a literatura que desenvolve essa proposição afirma que após as negociações multilaterais de Cancun o país viu urgência em concluir os acordos preferenciais cujas negociações já estavam em andamento, e em iniciar negociações com mais países.

Os Estados Unidos se engajaram em negociações multilaterais alternativas $(\mathrm{OECD})$, negociações regionais (ALCA ${ }^{25}, \mathrm{CAFTA}, \mathrm{SACU}^{26}$ ), negociações bilaterais (Chile, Cingapura, Austrália, Marrocos), opções legalizadas unilaterais (Seção 301) ${ }^{27}$ e multilaterais (MSC [Mecanismo de Solução de Controvérsias da OMC]). (CHOREV, 2007, p. 35, tradução nossa).

Becker e Blaas (2007) desenvolvem argumento semelhante; segundo eles:

Por um lado, [a troca de instituições multilaterais por instituições bilaterais ou plurilaterais] teve por objetivo o espalhamento de normas específicas ao menos em áreas geograficamente mais circunscritas, quando as chances de tê-las adotadas em nível global eram pequenas. (BECKER, BLAAS, 2007, p. 271, tradução nossa).

Além dos problemas verificados no âmbito da OMC, Díaz (2008) afirma que as tentativas frustradas de revisar dois tratados assinados na Organização Mundial da Propriedade Intelectual (OMPI) em 1996 (o “Tratado da Organização Mundial de Propriedade Intelectual sobre Direito de Autor" e o "Tratado da Organização Mundial de Propriedade Intelectual sobre Prestações e Fonogramas") ${ }^{28}$, também motivaram a estratégia dos Estados Unidos:

Como não será fácil que essas instituições multilaterais [OMC e OMPI] revisem os acordos de 1994 [Acordo GATT 1994/ Acordo TRIPS] e 1996, especialmente porque os países desenvolvidos ainda não estão dispostos a

25 Conforme explicaremos de modo mais detalhado abaixo, a falha nas negociações da ALCA é um elemento que, posteriormente, também contribuiu para que os Estados Unidos buscassem a assinatura de diversos acordos preferenciais, em particular com países latino-americanos.

26 "SACU” é a sigla em inglês para a União Aduaneira da África Austral, composta por África do Sul, Botsuana, Lesoto, Namíbia e Suazilândia. Diferenças quanto a subsídios agrícolas e regras antidumping dificultaram o alcance do acordo com esse grupo (CHOREV, 2007).

27 Em 1988, uma mudança na lei de comércio dos Estados Unidos, que deu origem à provisão comumente referenciada na literatura como Special 301, estabeleceu que o USTR deve investigar países suspeitos de violar interesses estadunidenses relacionados à propriedade intelectual; após a investigação, ele pode recomendar retaliações comerciais aos países considerados "violadores", as quais são prenúncios de eventuais sanções comerciais (SELL, 2003).

28 O objetivo do desses dois tratados era a adequação das normas multilaterais sobre direitos de autor já existentes às modificações decorrentes da crescente importância da internet; consistiram na "[...] [adaptação de normas de direitos de autor e conexos] enquanto 'respostas' às demandas emergentes das novas tecnologias de comunicação, especificando, esclarecendo e aprofundando o conteúdo de dispositivos normativos relacionados à utilização de obras de autoria nas redes digitais.” (POLIDO, 2010, p. 250). 
outorgar concessões em matéria de subsídios e proteção agrícola, os acordos de livre-comércio constituem uma forma de ir acumulando forças para futuras rodadas de negociações multilaterais. (DÍAZ, 2008, p. 89, tradução nossa). ${ }^{29}$

2 Dificuldades em âmbito regional: o segundo motivo pelo qual, segundo a literatura atualmente disponível, os Estados Unidos optaram por firmar acordos preferenciais, são dificuldades com alternativas de liberalização regionais. A ALCA é o exemplo mais mencionado.

O projeto da ALCA foi lançado em dezembro de 1994, em Miami, por iniciativa dos Estados Unidos, visando tornar toda a América em uma área de livre-comércio, e as negociações para sua criação foram iniciadas em 1998; de acordo com Becker e Blaas (2007), a ALCA foi uma resposta à formação do Mercosul em 1991, uma vez que os Estados Unidos temiam que o Brasil poderia tornar o bloco em um polo de atração alternativo aos estados da América do Sul.

Segundo Chorev (2007) as razões que levaram à falha na conclusão da ALCA se assemelham a algumas das razões pelas quais a Rodada Doha havia paralisado: a não concordância estadunidense com as reduções em subsídios agrícolas demandadas por suas contrapartes (os negociadores estadunidenses argumentavam que não poderiam fazer tais concessões em nível regional, uma vez que elas deveriam ser acompanhadas de reduções semelhantes da União Europeia e de outros países e que, portanto, a OMC era a instituição adequada para isso) ${ }^{30}$ e diferenças com países em desenvolvimento (no caso, o Brasil) quanto a propriedade intelectual e investimentos (o governo brasileiro anunciou, após o colapso em Cancun, que preferia um acordo de comércio regional que não incluísse a propriedade intelectual, serviços, investimentos e compras governamentais). ${ }^{31} \mathrm{Em} 2003$, em função dessas dificuldades, as negociações da ALCA foram interrompidas.

Os Estados Unidos foram compelidos a aceitar as novas condições, e na oitava reunião ministerial da ALCA, realizada em Miami em 20 e 21 de

29 A negociação de um novo tratado sobre patentes no âmbito da OMPI, o SPLT (Substantive Patent Law Treaty), iniciado em 2001 por requisição de um grupo de países desenvolvidos, entre os quais estavam os Estados Unidos, também não obteve sucesso devido a diferenças com vários países em desenvolvimento (DEERE, 2009; POLIDO, 2010).

30 O emprego desse mesmo argumento dificultou as negociações com a SACU, que mencionamos acima.

31 Segundo Becker e Blaas (2007), as reservas brasileiras ao acordo de livre-comércio foram essenciais para o insucesso das negociações. Nesse sentido, Cacciamali, Bobik e Celli Junior (2012) afirmam que "Com a expansão do Mercosul e a criação da Unasul, o Brasil contribuiu para desativar ou diminuir a importância de ações da diplomacia estadunidense, como o projeto da Alca e o Tratado Interamericano de Assistência Recíproca e o Tratado da Junta Interamericana de Defesa [...].” (CELLI JUNIOR; CACCIAMALI; BOBIK, 2012, p. 97). 
novembro de 2003, as partes concordaram com uma agenda mais estrita [...]. Os representantes dos Estados Unidos, frustrados com a possibilidade de um acordo de comércio hemisférico fraco, se focaram em acordos de livrecomércio com os Andes, os países da América Central e do Caribe. (CHOREV, 2007, p. 51, tradução nossa). ${ }^{32}$

Outro projeto regional, a Free Trade Area of the Asia-Pacific (FTAAP, Área de livrecomércio da Ásia-Pacífico, em tradução livre para o Português), tampouco obteve sucesso; ela foi proposta pelo conselho sobre negócios da APEC, e deveria ser composta pelos membros da APEC; a partir de 2006 os Estados Unidos passaram a defender tal proposta (DENT, 2013). Entretanto, segundo Dent (2013) muitos países do leste asiático não concordaram com o FTAAP por preferirem outras propostas de liberalização comercial, como a EAFTA (East Asia free trade Area, Área de livre-comércio do leste asiático, em livre tradução para o Português) ${ }^{33}$ e a CEPEA (Comprehensive Economic Partnership of East Asia, Parceria econômica abrangente do leste asiático, em livre tradução para o Português) ${ }^{34}$. Ademais, esses países que recusaram o FTAAP:

[...] estavam então preocupados em entrar em negociações de um acordo de livre-comércio regional que seria primariamente conduzido e conformado pelos interesses comerciais regulatórios dos Estados Unidos. Os projetos de acordos de livre-comércio bilaterais abortados por Washington com três nações do sudeste asiático por essa época (Malásia, Filipinas e Tailândia) devido a diferenças irreconciliáveis sobre certas áreas de regulação comercial foram instrutivas para outros estados do leste asiático sobre os desafios de se negociar com os Estados Unidos. (DENT, 2013, p. 976, tradução nossa).

Apesar desses insucessos regionais, uma iniciativa (que, embora não possa ser descrita como "regional", tampouco pode ser descrita como "multilateral" ou "bilateral") que obteve sucesso, foi o Anti-Counterfeiting Trade Agreement (ACTA), acordo assinado em 2011, mas cujas negociações foram iniciadas em outubro 2007, por iniciativa dos Estados Unidos, e que objetiva a construção de um novo framework internacional para os direitos de propriedade intelectual (MICARA, 2012; POLIDO, 2010). Segundo Polido (2010):

${ }^{32}$ Nos preâmbulos dos acordos preferenciais de comércio entre os Estados Unidos e países da América Latina aqui analisados são estabelecidas claras relações entre o conjunto dos acordos de comércio e a ALCA; mesmo no mais recente deles, o firmado com o Panamá em 2007, se afirma que entre os objetivos do acordo está "Contribuir com a integração hemisférica e prover um ímpeto em direção ao estabelecimento da Área de Livre-comércio das Américas.” (OFFICE OF THE UNITED STATES TRADE REPRESENTATIVE, 2007b, p. 2, tradução nossa).

33 O projeto da EAFTA tinha a China como principal propositora e sua composição se baseava na ASEAN mais a China, o Japão e a Coreia do Sul (DENT, 2013).

34 O projeto da CEPEA tinha o Japão como principal propositor e seus outros membros seriam os participantes da ASEAN somados à China, à Coreia do Sul, à Índia, à Austrália e à Nova Zelândia (DENT, 2013). 
Em suas manifestações expressando a iniciativa de negociações do ACTA [...] o USTR reitera que o objetivo principal do acordo seria a criação de um novo padrão de observância dos direitos de propriedade intelectual, superiores àqueles já acordados mutuamente em nível multilateral pelos Membros do TRIPS no contexto do GATT/OMC, e de uma rede de cooperação internacional, contemplando intercâmbio de informações entre os órgãos e agências responsáveis pela aplicação dos direitos de propriedade intelectual nos direitos domésticos. (POLIDO, 2010, p. 335).

Sobre o ACTA, Deere (2009) afirma que "[...] the stated goal of the initiative was to set a new, higher benchmark for enforcement that countries could join on a voluntary basis (thus avoiding the challenge of negotiating a treaty on this subject through an international organization)." (DEERE, 2009, p. 117, grifo nosso).

Os Estados Unidos estão entre os signatários do acordo final do ACTA (os demais são Austrália, Canadá, Cingapura, Coreia do Sul, Japão, Marrocos, México, Nova Zelândia e 22 dos membros da União Europeia) (SWISS FEDERAL INSTITUTE OF INTELLECTUAL PROPERTY, 2014). O Acordo é mais um componente da contínua expansão do vínculo jurídico internacional entre comércio e propriedade intelectual para além da OMC (da qual os Estados Unidos são um dos propagadores), pelo quê o ACTA constitui um indicador adicional da insatisfação estadunidense com a Organização.

\section{Acesso a mercados}

Quanto ao acesso a mercados, Becker e Blaas (2007) consideram que o fato de os Estados Unidos terem saldo negativo no comércio de bens e pagamentos de juros com a Europa e o leste da Ásia faz com que seja essencial que o país compense esses déficits através do superávit em seu balanço de pagamentos com outras regiões.

Esse é um forte incentivo para melhorar a influência dos Estados Unidos em regiões com uma posição tradicional forte do setor privado dos Estados Unidos, especialmente a América Latina, e provê um impulso para a negociação de acordos de livre-comércio com essas regiões, garantindo acesso privilegiado para companhias dos Estados Unidos. (BECKER; BLAAS, 2007, p. 274, tradução nossa). 
4 Interesse privado doméstico: substancial parte da literatura destaca a influência de setores produtivos estadunidenses intensivos em propriedade intelectual sobre a política comercial do país.

Chorev (2007), por exemplo, considera que nas negociações para a criação da "Declaração sobre o Acordo TRIPS e Saúde Pública", as grandes companhias farmacêuticas estadunidenses se opuseram à proposta do grupo de países em desenvolvimento. "A posição delas [das grandes companhias farmacêuticas] foi vigorosamente promovida pelos negociadores dos Estados Unidos." (CHOREV, 2007, p. 41, tradução nossa).

Díaz (2008) considera que essa relação entre o USTR e a indústria farmacêutica se estendeu às negociações dos acordos preferenciais firmados pelos Estados Unidos com países da América Latina: "Durante as negociações dos ALC [acordos de livre-comércio] com os Estados Unidos, o USTR representou quase diretamente os interesses de associações gremiais

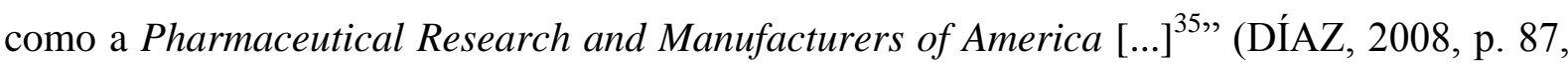
tradução nossa). Segundo Muzaka (2011) as indústrias farmacêuticas estadunidenses "pressionaram" para que os acordos preferenciais firmados pelos Estados Unidos exigissem a concessão de exclusividade de comercialização de medicamentos em função dos dados submetidos para a aprovação de comercialização dos mesmos, o que não é requerido pelo Acordo TRIPS (GENERAL AGREEMENT ON TARIFFS AND TRADE, 1994).

Sell (2007) também afirma ter havido influência de setores produtivos domésticos para a configuração dos capítulos sobre propriedade intelectual dos acordos preferenciais firmados pelos Estados Unidos após a entrada em vigor da OMC. Ela afirma que um dos comitês que auxiliam o USTR na formulação de políticas comerciais (o Industry Trade Advisory Comittee) tem entre seus componentes representantes de indústrias farmacêuticas, de biotecnologia, do entretenimento, de softwares e de editoras, os quais têm bastante interesse na criação e manutenção do cumprimento de normas sobre propriedade intelectual como as descritas pelo conceito de "TRIPS-plus",36. Ademais, Sell (2007) considera que as doações de campanha

35 Formada em 1958, a Pharmaceutical Research and Manufacturers of America (cuja sigla é "PhRMA") é uma associação que reúne 55 indústrias do setor farmacêutico e de biotecnologia dos Estados Unidos; é parte do Comitê de Propriedade Intelectual, que inclui também indústrias do entretenimento e produtoras de softwares. (PHARMACEUTICAL RESEARCH AND MANUFACTURERS OF AMERICA, 2015; SELL, 2003).

36 O conceito de "TRIPS-plus" é utilizado na literatura para descrever normas sobre propriedade intelectual negociadas ou aprovadas após a entrada em vigor do TRIPS que fazem requisições adicionais a tal acordo. Especificamente quanto a medicamentos, Sell (2007) afirma que as provisões sobre propriedade intelectual dos acordos preferenciais foram feitas de modo a reduzir a disponibilidade de medicamentos genéricos, dificultar a emissão de licenças compulsórias e dificultar a consecução de importações paralelas, características que atenderiam a demandas das indústrias farmacêuticas detentoras de patentes. 
feitas por indústrias farmacêuticas são explicativas da preferência que os Estados Unidos manifestaram quanto à propriedade intelectual em seus acordos preferenciais:

[...] nas eleições parlamentares dos Estados Unidos de novembro de 2002 um grupo de firmas globais da PhRMA, encabeçadas pelo CEO da Pfizer, Hank McKinnell, levantou US\$30 milhões para as campanhas do Partido Republicano. Não coincidentemente, a administração de Bush deu tanto apoio e foi tão responsiva aos objetivos e estratégias da indústria farmacêutica global. (SELL, 2007, p. 52, tradução nossa).

No mesmo sentido, Fink e Reichenmiller (2006) consideram que os setores produtivos exportadores de bens protegidos por direitos de propriedade intelectual apoiaram a assinatura dos acordos preferenciais de comércio. Muzaka (2011) concorda com essa interpretação, e a estende ao Acordo TRIPS:

A mais importante ligação, aquela entre a propriedade intelectual e o comércio institucionalizada no Acordo TRIPS (e depois nos acordos de livre-comércio), foi um claro sucesso dos estados ricos em propriedade intelectual e de atores privados [business actors, no original] [...]. (MUZAKA, 2011, p. 123, tradução nossa).

Díaz (2008) menciona também a influência de outros atores domésticos nos Estados Unidos:

A isso [influência das indústrias farmacêuticas e as preocupações manifestadas pelos países latino-americanos quanto a eventuais excessos nas normas sobre patentes] se agregaram as pressões da coalizão de acadêmicos e organizações não governamentais dos Estados Unidos, que conseguiram desenvolver uma importante capacidade de influenciar no Congresso estadunidense. (DÍAZ, 2008, p. 87, tradução nossa).

Embora seja extensa a literatura que afirma que as indústrias de bens tipicamente protegidos por direitos de propriedade intelectual influencia a política comercial dos Estados Unidos (e, conforme veremos na seção 4, os interesses dessas indústrias em larga medida se refletiram nos acordos firmados pelos Estados Unidos com países da América Latina), a literatura sobre a influência desses outros atores mencionados por Díaz (2008) é menos abundante, não especificando de que modo esses interesses divergentes interagiram para a configuração da política praticada pelos Estados Unidos. 
5 Insatisfação com as práticas sobre propriedade intelectual de outros países: Díaz (2008), escrevendo acerca dos acordos de comércio com países da América Latina, afirma que os Estados Unidos consideravam, quanto à proteção de direitos de propriedade intelectual, que os procedimentos administrativos, judiciais e civis de suas contrapartes não eram eficazes, e que não incorporavam diretamente os desenvolvimentos tecnológicos relacionados à internet e às tecnologias digitais. Assim:

[...] 50\% dos capítulos de propriedade intelectual centra a atenção na observância e em medidas tecnológicas de proteção, já que o USTR procurou explicitamente que as disposições a esse respeito se igualassem tanto quanto possível ao modelo vigente nos Estados Unidos. Assim, desde a perspectiva das empresas estadunidenses, se reduziriam os custos de transação e haveria maior segurança processual, mas também se evitaria que os países da região adotassem outros modelos de observância e proteção das MTP [medidas tecnológicas de proteção] ${ }^{37}$ [...]. (DÍAZ, 2008, p. 100, tradução nossa).

Deere (2009) concorda com essa interpretação, e enfatiza que os Estados Unidos consideravam inadequado o modo como o Acordo TRIPS e outros tratados internacionais sobre propriedade intelectual vinham sendo implementados, e que viram nos acordos preferenciais um meio para induzir mudanças, quanto aos direitos de propriedade intelectual, em países em desenvolvimento. Gillman (2009) afirma que os Estados Unidos obtiveram sucesso em produzir essas mudanças nos acordos preferenciais que firmou com países latinoamericanos.

No mesmo sentido, Micara (2012) afirma que ao longo da década de 2000 as investigações do USTR concluíram que muitos países tinham nível de proteção inadequado a produtos farmacêuticos, sendo que a proteção aos dados submetidos para aprovação para comercialização era considerada particularmente preocupante pelo Office.

Esse levantamento bibliográfico foi suficiente para indicar que a literatura acadêmica considera haver um conjunto de razões para que os Estados Unidos tenham, ao longo da década de 2000, assinado diversos acordos preferenciais de comércio, e em todos eles inserido capítulos sobre propriedade intelectual. As razões relacionadas à propriedade intelectual na OMC e na OMPI se somaram às dificuldades quanto a outros temas na OMC (notadamente a

37 Para a definição de "MTP”, cf. seção 4.2, abaixo. Díaz (2008) afirma que as MTP não são diretamente tratadas pelos acordos da OMPI ou pelo Acordo TRIPS e que, ao menos quanto aos acordos preferenciais firmados com países da América Latina, os Estados Unidos pretendiam potencializar as MTP, de modo a assegurar punições a infratores das mesmas. 
liberalização agrícola); às dificuldades nas negociações de acordos de comércio amplos, mas não multilaterais (ALCA e FTAAP); à intenção de ampliar mercados a bens industrializados e serviços; às demandas de setores domésticos produtores de bens tipicamente protegidos por direitos de propriedade intelectual; e à intenção de modificar sistemas estrangeiros de proteção aos direitos de propriedade intelectual. Embora a maioria das motivações apresentadas sejam gerais (dizendo respeito à política "preferencial" estadunidense como um todo), a falha da ALCA e a intenção de consolidar as relações econômicas (superavitárias aos Estados Unidos) dizem respeito em particular à inclinação estadunidense de assinar acordos de comércio com diversos países latino-americanos, conforme explicamos acima.

Em 2007, em função de diversas exigências parlamentares (dentre as quais algumas eram relativas aos direitos de propriedade intelectual), os Estados Unidos tiveram que voltar a negociar com algumas de suas contrapartes. Se o USTR não tivesse observado as diretrizes parlamentares (tanto as de 2002 quanto as de 2007) ao negociar acordos de comércio, e o presidente submetesse tais acordos imperfeitos ao Congresso, eles provavelmente não teriam sido ratificados; o fast track inibiu tal possibilidade adversa não somente por ter instruído os negociadores federais, mas também por ter permitido a participação direta de parlamentares nas negociações.

Os resultados práticos dessas preferências domesticamente consolidadas nos Estados Unidos dependeram, entretanto, da interação do país com as suas contrapartes nos acordos, de modo que eles não necessariamente refletem perfeitamente os objetivos dos Estados Unidos, podendo haver, portanto, discrepâncias entre os acordos de comércio (ou seja, os acordos podem ter graus variados de proximidade em relação à preferência estadunidense). ${ }^{38}$

Na próxima seção compararemos entre si os capítulos sobre propriedade intelectual dos acordos de comércio firmados pelos Estados Unidos com países da América Latina durante a década de 2000, de modo que tais diferenças serão explicitadas.

\footnotetext{
38 Ao admitir que as diferenças entre os acordos de comércio podem ter decorrido de uma interação com as contrapartes dos Estados Unidos, evitamos incorrer no que Frieden (1999) chama de "pecados de comissão", que consistem "[...] na falácia lógica de afirmar que aqueles mais beneficiados por um resultado necessariamente devem ter determinado o resultado, ignorando a possibilidade que uma interação estratégica possa ter fundamentalmente transformado o processo e seu ponto final.” (FRIEDEN, 1999, p. 52, tradução nossa). Nesse sentido, Díaz (2008) afirma que as diferenças existentes entre os capítulos de propriedade intelectual dos acordos firmados pelos Estados Unidos com países latino-americanos em parte se devem a exigências feitas pelas contrapartes dos Estados Unidos nas negociações (ou seja, pelos países latinoamericanos signatários).
} 


\section{ANÁLISE COMPARATIVA ENTRE OS CAPÍTULOS SOBRE PROPRIEDADE INTELECTUAL DOS ACORDOS PREFERENCIAIS DE COMÉRCIO FIRMADOS PELOS ESTADOS UNIDOS COM PAÍSES LATINO-AMERICANOS NA DÉCADA DE 2000}

Na seção precedente verificamos quais motivos levaram os Estados Unidos a firmar diversos acordos preferenciais de comércio no período analisado, em particular quanto aos seus capítulos sobre propriedade intelectual contidos nos acordos com países latinoamericanos; podemos agora analisar as características jurídicas, legais, de tais capítulos. Eles são relativamente extensos: assim como o TRIPS, determinam diretrizes aplicáveis a todos os direitos de propriedade intelectual existentes nos sistemas jurídicos de seus signatários; entretanto, os acordos preferenciais são, quando comparados com o Acordo TRIPS, mais específicos quanto aos direitos incidentes sobre diversas inovações tecnológicas, e contêm mais detalhamentos sobre os direitos relacionados a produtos farmacêuticos e químicos para agricultura. Ademais, os acordos preferenciais contêm "side letters", documentos firmados em conjunto com os acordos que esclarecem o conteúdo dos mesmos ou estabelecem novos compromissos entre as partes.

Entre as seções 4.1 e 4.9, nos focaremos na comparação entre os capítulos sobre propriedade intelectual dos acordos preferenciais e o Acordo TRIPS da OMC (e, por consequência, em quais são os novos compromissos internacionais que eles geraram a seus signatários); também enfatizaremos quais são as diferenças entre os capítulos.

\subsection{Assinatura de terceiros acordos sobre propriedade intelectual}

Quando os países latino-americanos firmaram seus acordos de comércio com os Estados Unidos, eles já eram membros da OMC, de modo que o Acordo TRIPS estava em vigor para eles. Assim, utilizamos o Acordo TRIPS como um referencial de análise ao longo da seção 4.1; avaliamos os "novos" compromissos sobre propriedade intelectual aos países signatários dos acordos preferenciais na medida em que acrescentam compromissos aos já anteriormente assumidos sob o TRIPS.

Dentre os mencionados compromissos adicionais estão os relacionados à assinatura de novos acordos sobre propriedade intelectual: os acordos preferenciais exigem que seus 
membros assinem ou ratifiquem diversos outros acordos. A Tabela 1, abaixo, mostra quais são esses acordos, e a data em que cada país confirmou sua adesão a eles ${ }^{39}$.

39 Os acordos de comércio recomendam a assinatura do "Protocolo referente ao Acordo de Madrid Relativo ao Registro Internacional de Marcas", do "Acordo de Haia Relativo ao Registro Internacional de Desenhos Industriais" e do "Acordo sobre Direito de Patentes", mas suas partes não se comprometeram a assinar os mesmos; portanto, não estão incluídos na tabela 1. 


\begin{tabular}{|c|c|c|c|c|c|c|c|c|c|c|c|}
\hline & $\begin{array}{l}\text { Estados } \\
\text { Unidos }\end{array}$ & Chile $^{40}$ & $\begin{array}{l}\text { Costa } \\
\text { Rica }\end{array}$ & $\begin{array}{c}\text { El } \\
\text { Salvador }\end{array}$ & Guatemala & Honduras & Nicarágua & $\begin{array}{l}\text { República } \\
\text { Dominicana }\end{array}$ & Peru & Colômbia & Panamá \\
\hline $\begin{array}{c}\text { Tratado de } \\
\text { Cooperação em } \\
\text { Matéria de } \\
\text { Patentes (1979) }\end{array}$ & $11 / 1975^{41}$ & $\underline{03 / 2009}$ & $05 / 1999$ & $\underline{05 / 2006}$ & $\underline{07 / 2006}$ & $\underline{03 / 2006}$ & $12 / 2002$ & $02 / 2007$ & $\underline{03 / 2009}$ & $11 / 2000$ & $\underline{06 / 2012}$ \\
\hline $\begin{array}{c}\text { Convenção } \\
\text { Relativa à } \\
\text { Distribuição de } \\
\text { Sinais Portadores } \\
\text { de Programas } \\
\text { Transmitidos por } \\
\text { Satélite }\end{array}$ & $12 / 1984$ & $\underline{03 / 2011}$ & $03 / 1999$ & $\underline{04 / 2008}$ & - & $01 / 2008$ & $12 / 1975$ & - & $05 / 1985$ & $\underline{12 / 2013}$ & $06 / 1985$ \\
\hline $\begin{array}{c}\text { Tratado de } \\
\text { Budapeste sobre } \\
\text { o reconhecimento } \\
\text { internacional dos } \\
\text { depósitos de }\end{array}$ & $09 / 1979$ & $05 / 2011$ & $06 / 2008$ & $\underline{05 / 2006}$ & $07 / 2006$ & $03 / 2006$ & $05 / 2006$ & $04 / 2007$ & $10 / 2008$ & $\underline{02 / 2012}$ & $\underline{06 / 2012}$ \\
\hline
\end{tabular}

40 O Chile se comprometeu a aderir ao "Tratado de Cooperação em Matéria de Patentes" tal como emendado em 1984, enquanto os demais países se comprometeram a fazêlo em relação ao texto decorrente de emendas feitas em 1979; o texto original no qual ambas as emendas se baseiam é de 1970. Somente no acordo chileno os membros afirmaram que se guiariam pelos princípios estabelecidos na "Recomendação Conjunta Relativa às Provisões sobre a Proteção de Marcas Bem Conhecidas", de 1999, adotada pela Assembleia Geral da OMPI. Ademais, o Chile foi o único país que não se comprometeu com os Estados Unidos a aderir ao "Tratado de Budapeste", ao "Tratado da OMPI sobre Direito de Autor" e ao "Tratado da OMPI sobre Prestações e Fonogramas".

41 A data mostrada na tabela corresponde à adesão dos Estados Unidos ao "Tratado de Cooperação em Matéria de Patentes" original, de 1970; além da emenda realizada em 1979, foram realizadas emendas em 1984 e 2001. 


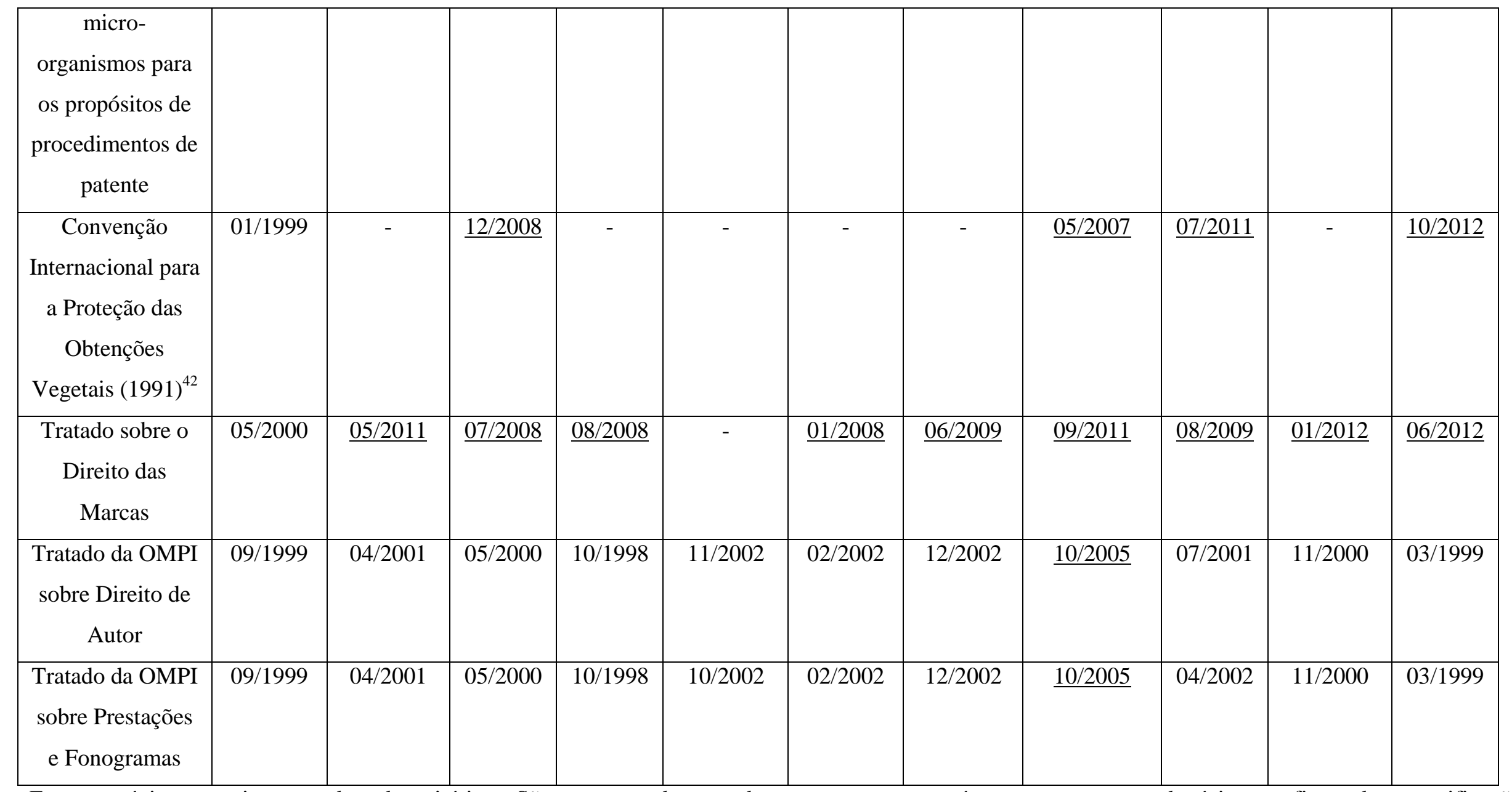

Fontes: páginas na internet dos depositários. São apresentadas as datas em que os países entregaram o depósito confirmando a ratificação. 42 As referências dizem respeito à Convenção tal como emendada em 1991 apenas (o Chile, a Nicarágua e a Colômbia são membros da UPOV com base no texto de 1978, ou
seja, esses países ainda não depositaram um instrumento de concordância com a revisão realizada em 1991). 
Na tabela, as datas sublinhadas indicam adesões feitas após os países correspondentes terem concluído seu acordo de comércio com os Estados Unidos. Nota-se que os Estados Unidos já eram parte de todos os acordos sobre propriedade intelectual cuja adesão é obrigatória pelos acordos de comércio. Um caso peculiar é o da República Dominicana, que não havia aderido a qualquer dos tratados listados acima antes da assinatura de seu acordo de comércio com os Estados Unidos; a Guatemala tem a adesão mais baixa, pois até o momento lhe resta aderir a três dos tratados requeridos. A Costa Rica é o único membro do CAFTA-DR que já aderiu a todos os acordos sobre propriedade intelectual requeridos em seu acordo de comércio com os Estados Unidos.

Outra característica que se destaca na tabela é que o "Tratado de Budapeste sobre o reconhecimento internacional de micro-organismos para os propósitos de patente" e o “Tratado sobre o Direito das Marcas" foram os que tiveram maior adesão entre os países latino-americanos sob análise após eles terem assinado seus acordos de comércio com os Estados Unidos.

Nove países da América Latina já haviam aderido ao "Tratado da OMPI sobre Direito de Autor" e ao "Tratado da OMPI sobre Prestações e Fonogramas" no momento em que firmaram seu tratado de comércio com os Estados Unidos; em ambos os casos, somente a República Dominicana não era ainda signatária.

Nota-se, ademais, que os países latino-americanos já eram parte de muitos dos tratados sobre propriedade intelectual cuja adesão lhes era mandatória pelo acordo de comércio com os Estados Unidos. A uma primeira vista o fato de os Estados Unidos e todos os países latinoamericanos (com a exceção da República Dominicana) terem se comprometido a aderir a acordos sobre propriedade intelectual dos quais já eram parte parece uma atitude redundante; entretanto, a adesão aos mencionados acordos é "reforçada", uma vez que se algum dos países denuncia a um dos acordos listados ele estará infringindo uma cláusula de seu acordo de comércio, o que pode resultar, notadamente para os países latino-americanos, em retaliações significativas.

Embora os dados pareçam indicar que os acordos de comércio com os Estados Unidos tenham levado seus signatários latino-americanos a assinar vários acordos internacionais sobre propriedade intelectual, é impossível que afirmemos que tais assinaturas decorreram do acordo de comércio com os Estados Unidos, uma vez que elas podem ser decorrentes de outros acordos de comércio que os países latino-americanos tenham firmado, ou ainda de outros motivos. 


\subsection{Inovações tecnológicas}

Embora o Acordo TRIPS estenda a validade de suas normas a todos os direitos de propriedade intelectual de seus membros (tanto em relação à existente no momento em que ele entrou em vigor quanto à que fosse posteriormente adotada), ele não trata diretamente de tecnologias que foram criadas ou tiveram suas importâncias econômicas aumentadas desde 1994. Abaixo listamos tais tecnologias, resumindo as principais provisões a elas relativas nos acordos preferenciais:

- Internet: a internet adquiriu enorme importância desde meados da década de 1990, e não há uma menção sequer a ela no Acordo TRIPS. A internet é relevante em relação aos direitos de propriedade intelectual porque facilita a difusão, o armazenamento e o intercâmbio de materiais em formato digital que podem estar sujeitos a direitos de cópia ou correlatos (ou seja, a direitos aplicáveis a textos, gravações sonoras ou expressões artísticas).

Todos os acordos preferenciais de comércio firmados pelos Estados Unidos com países da América Latina estendem os direitos de propriedade intelectual à rede mundial de computadores. Os acordos preferenciais estendem a proteção dos direitos de propriedade intelectual a materiais digitais; apesar de tal provisão, por si só, já incluir a internet, as especificações quanto à última nos acordos preferenciais vão muito mais além.

Todos os acordos contêm uma delimitação bastante específica acerca dos direitos e obrigações de provedores de serviços de internet ${ }^{43}$. Tais provedores não podem ser responsabilizados pelo intercâmbio ou armazenamento de conteúdos protegidos que sejam feitos sem a autorização do titular dos direitos correspondentes, mas eles devem ter estrutura para receber notificações acerca da presença de materiais infratores nas redes por eles controladas, remover tais materiais, permitir que os responsáveis por materiais supostamente infratores se manifestem, informar a identidade dos infratores aos detentores dos direitos incidentes sobre os materiais, e remover as contas de infratores reincidentes. Ademais, os provedores devem, após determinação judicial, finalizar determinadas contas ou fazer todo o possível para impedir o acesso a determinados endereços da rede.

\footnotetext{
43 A definição de "provedor de serviço" é idêntica em todos os acordos; tais provedores são tanto "[...] um provedor de transmissão, direcionamento [routing, no oringinal], ou conexões para comunicações digitais online sem modificação de conteúdo entre pontos especificados pelo usuário de material de sua própria escolha [...]" quanto "um provedor ou operador de instalações para serviços online ou acesso a redes." (OFFICE OF THE UNITED STATES TRADE REPRESENTATIVE, 2006a, p. 31, tradução nossa).
} 
Por fim, apesar das obrigações mencionadas acima, os provedores não são obrigados a monitorar seu serviço, de modo que não cabe a eles o ônus de identificar os materiais infratores online ${ }^{44}$. Em todos os casos, o fórum competente para resoluções de disputas envolvendo direitos de cópia ou correlatos na internet deve estar na jurisdição onde o provedor está sediado.

Outra categoria de objetos relacionada à internet que foi diretamente abordada em todos os acordos de comércio é a dos "nomes de domínio". O objetivo das provisões é evitar que os endereços online infrinjam marcas registradas. Para tanto, os membros concordam em determinar que seus órgãos técnicos responsáveis por gerenciar seus endereços de internet adotem procedimentos para solução de disputas com base no Uniform Domain-Name Dispute-Resolution Policy. Ademais, os acordos exigem que seus membros criem bases de dados com informações de contato dos registradores de endereços da internet.

Somente no acordo com a Colômbia as partes não afirmam que, ao constituir a base de dados sobre registro de endereços na internet, as leis domésticas sobre proteção da privacidade devem ser levadas em conta.

Por fim, uma exigência relacionada com a internet presente nos acordos (com exceção do acordo com o Chile) é a proibição de que sinais de televisão sejam retransmitidos online sem a autorização dos detentores dos direitos de propriedade intelectual incidentes sobre os conteúdos exibidos (ou sem a autorização do difusor, o qual é considerado proprietário do sinal original difundido).

As provisões sobre internet são as mais uniformes dos capítulos sobre propriedade intelectual dos acordos preferenciais de comércio analisados.

- Medidas tecnológicas de proteção: os acordos de comércio criminalizam quaisquer atividades que tornem ineficazes as medidas tecnológicas de proteção; tais medidas (chamadas effective technological measures, nos originais em Inglês dos acordos preferenciais) são assim definidas em tais acordos:

[...] quaisquer tecnologias, aparelhos ou componentes que, no curso de sua operação, controlem o acesso a um trabalho protegido, apresentação artística ou gravação sonora, ou protejam quaisquer direitos de cópia ou quaisquer direitos correlatos a direitos de cópia. (OFFICE OF THE UNITED STATES TRADE REPRESENTATIVE, 2006a, p. 11, tradução nossa).

44 Quando há divergência entre quem disponibiliza o material e o reclamante, tampouco é de responsabilidade do provedor determinar se o material deve ou não permanecer online, tarefa que cabe ao judiciário. 
Segundo Díaz (2008), as medidas tecnológicas de proteção “[...] controlam o acesso, a reprodução e a distribuição de material protegido por direitos de cópia, direitos correlatos, ou ambos.” (DÍAZ, 2008, p. 59, tradução nossa). Segundo o autor, elas podem se aplicar a gravações contidas em discos de DVD, livros eletrônicos, equipamentos de videogame, transmissões pela internet e páginas na internet protegidas por senhas de acesso; as medidas, ainda segundo Díaz (2008) também se estendem a mecanismos que dificultam a realização de cópias de materiais protegidos.

O acordo chileno é o único a afirmar que seus membros, ao punir infratores de medidas tecnológicas de proteção, devem levar em conta se a infração foi motivada por um propósito científico ou educacional (o que provavelmente os levaria a determinar sanções mais brandas a esse tipo de infração, ou optar por não aplicá-las).

- Informações sobre gerenciamento de direitos: os acordos de comércio criminalizam a remoção desautorizada de informações sobre gerenciamento de direitos; tais informações são aquelas afixadas a uma cópia de um produto coberto por direito de cópia ou correlato (ou exibidas durante a disponibilização pública do produto) e que têm por objetivo informar o usuário acerca dos direitos incidentes sobre tal produto, tais como as condições para seu uso legal.

- Transmissões criptografadas por satélite e sinais de televisão: os acordos de comércio criminalizam a recepção (bem como eventual posterior distribuição) de sinais de satélite criptografados sem a autorização do emissor. O acordo com o Chile e o CAFTA-DR afirmam, ademais, que os emissores prejudicados por infrações a seus direitos de propriedade intelectual podem iniciar ações judiciais civis contra os infratores; com exceção do acordo com o Chile, todos os demais afirmam que as partes prejudicadas podem receber reparações em decorrência da infração a seus direitos.

Outra provisão específica a respeito de transmissões por satélite está presente no acordo colombiano, no qual a Colômbia afirma, em uma side letter, que provedores de serviço de televisão por assinatura não podem modificar o conteúdo de sinais de televisão que estejam sujeitos a uma cota mínima de conteúdo nacional.

A República Dominicana, dentre todos os países com os quais os Estados Unidos firmaram acordos preferenciais de comércio desde a entrada em vigor do Acordo TRIPS, é o que assumiu compromissos mais detalhados quanto à transmissão, por emissoras de televisão, de conteúdos sujeitos a direitos de propriedade intelectual: o país se comprometeu, em uma 
side letter firmada com os Estados Unidos, a interromper por completo as transmissões infratoras, e a impedir que futuras transmissões desse tipo ocorram; ademais, a República Dominicana se comprometeu a enviar relatórios trimestrais aos Estados Unidos relatando as ações que tomou no período quanto às transmissões televisivas não autorizadas de material protegido por direito de propriedade intelectual. Ademais, em um anexo ao capítulo sobre propriedade intelectual do CAFTA-DR, a República Dominicana também se comprometeu a suspender (temporariamente ou definitivamente) as transmissões de emissoras que retransmitam sinais sem a autorização de seu emissor original, a permitir que os detentores dos direitos sobre o sinal original peticionem a interrupção da retransmissão ilegal, e a tomar providências quanto à reclamação em até 60 dias.

\subsection{Direitos de cópia e correlatos}

Os direitos de cópia se estendem a cópias de publicações, enquanto os direitos "correlatos" se aplicam a cópias de gravações sonoras e a expressões artísticas. Embora tais direitos já fossem protegidos pelo TRIPS, nos acordos preferenciais o tempo de proteção é aumentado: enquanto no acordo multilateral o tempo de exclusividade conferido por um direito de cópia ou correlato era de $50 \operatorname{anos}^{45}$, nos acordos preferenciais tal tempo aumentou: a proteção deve durar ao menos: o tempo de vida do detentor acrescido de 70 anos; 70 anos após a publicação autorizada do trabalho ou, não tendo havido uma publicação autorizada, 70 anos a contar do final do ano em que a obra foi criada, desde que tal criação tenha ocorrido há até 50 anos antes da data de concessão do direito exclusivo. Quanto a esse aspecto, o acordo com o Chile tem uma pequena diferença: quando o direito de cópia incidente sobre gravações sonoras e apresentações artísticas é concedido com base no tempo de vida de uma pessoa, não há um tempo de proteção especificado de validade após a morte da pessoa, o que permite a interpretação de que a proteção em questão cessa com a morte do titular ${ }^{46}$.

Os acordos de comércio estendem a proteção dos direitos de cópia e correlatos a materiais disponibilizados ao público de forma que possam ser acessados em lugares e

45 O TRIPS permite a proteção de direitos de cópia: pelo tempo de vida da pessoa ou por 50 anos após publicação autorizada da obra (quando não há uma publicação autorizada, o tempo é de 50 anos após a data de criação). O tempo estabelecido para a proteção a gravações sonoras e apresentações artísticas é de 50 anos após o final do ano no qual a gravação ou realização da obra ocorreram.

46 O acordo com o Chile também é o único a não especificar um tempo mínimo de validade de direitos de marcas concedidos; nos demais acordos preferenciais, tal tempo mínimo é de dez anos, três a mais do que o determinado no TRIPS. 
momentos individualmente escolhidos pelos usuários, o que provavelmente teve por função a extensão de tais direitos à internet e a equipamentos portáteis.

O acordo com o Chile é o único a explicitar que suas partes podem aplicar o princípio de reciprocidade quanto ao uso de gravações sonoras em radiodifusões analógicas e abertas (ou seja, elas podem conceder a nacionais da contraparte um tratamento equivalente ao oferecido a seus nacionais naquele país). Apesar de os demais acordos de comércio não conterem tal orientação, eles podem aplicar limitações aos direitos conferidos a artistas no que tange a radiodifusões abertas (e, portanto, pode-se interpretar que eles são livres para aplicar o princípio de reciprocidade quanto ao uso de gravações sonoras em radiodifusões analógicas e abertas).

A Colômbia é o único país a afirmar que pode adotar medidas para assegurar que conteúdos audiovisuais produzidos no país que sejam distribuídos por serviços de áudio e vídeo interativos instalados em seu território sejam feitos "prontamente disponíveis" a seus consumidores. Quando tais medidas impliquem em discriminação contra empresas estrangeiras, entretanto, elas devem contar com a concordância do país estrangeiro afetado, e deve haver compensações no setor audiovisual que resultem em maior liberalização.

Outro aspecto dissimilar entre os capítulos é quanto à possibilidade de derrogar da aplicação do princípio de nação mais favorecida no caso de projetos de cooperação cultural internacional (somente Chile, Costa Rica, Peru e Colômbia se reservam, em side letters, essa possibilidade). Não é esclarecido em qualquer dos capítulos de que forma essa reserva será aplicada caso conflite com algum dos compromissos sobre propriedade intelectual assumidos nos acordos de comércio. Ademais, Peru e Colômbia afirmam que adotarão o princípio de reciprocidade a artistas e publicadores estrangeiros (ou seja, os direitos dos últimos serão condicionados ao tratamento concedido a nacionais peruanos e colombianos no país de nacionalidade de tais estrangeiros); igualmente, a interação dessas provisões com os direitos de propriedade intelectual não é esclarecida.

\subsection{Especificações sobre produtos químicos para a agricultura e farmacêuticos}

Os acordos de comércio analisados, diferentemente do acordo multilateral, são dotados de diversas normas específicas relacionadas à concessão de períodos de exclusividade na comercialização de produtos farmacêuticos e químicos para a agricultura com base em dados 
de testes submetidos para sua aprovação para comercialização ${ }^{47}$. Em todos os casos, trata-se de produtos que estão pela primeira vez tendo sua comercialização requisitada, mas eles não necessariamente estão protegidos por patentes.

O tempo de proteção conferido a produtos químicos para agricultura com base em dados submetidos para aprovação para comercialização é de ao menos dez anos (nos acordo com o Chile, com os membros do CAFTA-DR e com o Peru; nos acordos com Colômbia e Panamá o tempo não é delimitado ${ }^{48}$. Com exceção do acordo com a Colômbia, todos os demais afirmam que, caso as partes já tivessem sistemas que conferissem proteção a produtos farmacêuticos e/ou químicos para a agricultura que durasse menos do que o especificado nos acordos de comércio, elas poderiam manter tais sistemas.

Os acordos de comércio permitem que informações concernentes a patentes (as subject matter of a subsisting patent conforme aparecem nos originais) sejam utilizadas para apoiar pedidos de comercialização de medicamentos, mas enfatizam que tal uso deve ser estritamente feito para apoiar o pedido, não podendo o produto resultante do dado de teste revelado ser produzido com outros fins, ou ser inserido no mercado (ademais, sempre que haja uma requisição de uso dos dados para apoiar um pedido de comercialização de medicamento, o fornecedor dos dados deve ser informado sobre a identidade do requisitante).

Os acordos de comércio determinam que quando os dados de testes são importados, os direitos exclusivos de comercialização devem ser conferidos ao fornecedor original dos dados (ou seja, aquele localizado no exterior); os acordos com o Peru, a Colômbia e o Panamá são mais exigentes, pois afirmam que no caso de químicos para a agricultura, o fornecedor original pode ter que fazer uma requisição para tanto (ou seja, o reconhecimento não é "automático"). O acordo com o Chile é o único a não mencionar a possibilidade de importação de dados de teste.

Uma característica presente somente no acordo com o Chile é que nele se afirma que as partes somente concederão a terceiros aprovações para comercialização de produtos farmacêuticos que estejam submetidos a patentes uma vez que as patentes sobre eles incidentes tenham expirado (ou seja, durante esse período não é permitida sequer a concessão de autorização para comercialização, o que pode atrasar o ingresso de produtos genéricos no

\footnotetext{
47 O Acordo TRIPS determina a proteção de dados submetidos para a aprovação de comercialização de produtos químicos para a agricultura e farmacêuticos contra "uso comercial injusto", sem realizar mais detalhamentos.

48 Sobre o período correspondente aos produtos farmacêuticos, cf. seção 4.9, abaixo.
} 
mercado pois, na ausência dessa provisão, produtos genéricos poderiam estar disponíveis imediatamente após o término da patente) $)^{49}$.

\subsection{Compromisso com a "Declaração sobre o Acordo TRIPS e Saúde Pública"}

Os acordos preferenciais, apesar de terem as diferenças em relação ao Acordo TRIPS que temos destacado aqui, não extinguiram os compromissos que seus membros tinham em decorrência dos acordos da OMC (pelo contrário, nos acordos preferenciais as partes reafirmaram sua observação ao TRIPS). Os membros dos acordos preferenciais também reafirmaram seu compromisso com a "Declaração sobre o Acordo TRIPS e Saúde Pública", adotada em 2001 na OMC; o CAFTA-DR e os acordos subsequentes são mais completos, pois afirmam que suas partes se reunirão para adequar seus compromissos no caso de o TRIPS ser emendado em decorrência da Declaração, e afirmam que eles podem tomar medidas para assegurar o acesso a medicamentos por toda a população (a única diferença nesse sentido é que, enquanto os compromissos dos membros do CAFTA-DR estão expressos em uma side letter, os dos demais países estão expressos no texto do capítulo sobre propriedade intelectual de seus acordos preferenciais). Não é esclarecido qual princípio deve prevalecer caso a provisão de medicamentos com base nessas afirmações conflite com direitos de patente.

4.6 Recursos genéticos e conhecimentos tradicionais

Nos acordos com o Peru e com a Colômbia se afirma que caso patentes incidam sobre recursos genéticos, as "autoridades apropriadas" devem ser consultadas (sem que tais "autoridades" sejam especificadas); afirma-se, ademais, que as partes devem criar bases de dados contendo informações que possam afetar o patenteamento de invenções baseadas em recursos genéticos e em conhecimentos tradicionais. O acordo com o Panamá afirma somente que seus membros cooperarão na OMPI em temas relacionados a conhecimentos tradicionais e recursos genéticos (sem especificar a natureza dessa cooperação), e que eles realizarão

49 Nos demais acordos se afirma que os governos “[...] devem implementar medidas em seu sistema de aprovação para comercialização para evitar que essas outras pessoas [referindo-se a solicitantes de dados de teste já existentes] comercializem um produto coberto por uma patente [...] durante o termo daquela patente [...]” (OFFICE OF THE UNITED STATES TRADE REPRESENTATIVE, 2004, p. 18, tradução nossa, grifo nosso). Assim, embora a comercialização dos medicamentos genéricos seja proibida durante a validade da patente, nada impede os signatários de conceder a aprovação para comercialização antes do final da validade da mesma, de modo que medicamentos genéricos estejam disponíveis imediatamente após o término de validade das patentes a eles correspondentes. 
consultas entre si no caso de um deles assinar algum acordo sobre recursos genéticos ou conhecimentos tradicionais com um terceiro país.

Os membros do CAFTA-DR, apesar de não terem assumido quaisquer compromissos específicos sobre esses temas, afirmaram que o fato de eles terem se comprometido a assinar a “Convenção Internacional para a Proteção das Obtenções Vegetais” não implica em que eles deixem de conservar seus recursos genéticos. Tanto os compromissos dos membros do CAFTA-DR quanto os de Peru, Colômbia e Panamá supramencionados estão expressos em side letters.

4.7 Provisões sobre o cumprimento dos capítulos sobre propriedade intelectual

Parte expressiva do conteúdo dos capítulos sobre propriedade intelectual é dedicada a determinar normas para o enforcement, ou seja, a determinar procedimentos judiciais, técnicos e administrativos que devem ser adotados em relação a infrações de direitos de propriedade intelectual (ou à prevenção de infrações), bem como a determinar quais ações os detentores de direitos de propriedade intelectual podem requisitar às autoridades administrativas e judiciárias no caso de supostas infrações.

Uma prerrogativa atribuída aos detentores de direitos de propriedade intelectual presente no acordo com o Peru e com a Colômbia, e que estava ausente no Acordo TRIPS, é a de eles requisitarem que bens que tenham sido determinados como "infratores" pelo judiciário sejam destruídos (enquanto no acordo multilateral tal destruição ficava por conta da discricionariedade do judiciário). Outra prerrogativa "nova", presente em todos os acordos, é que a justiça deve determinar que os infratores revelem as identidades de outras pessoas envolvidas em infrações e os canais de distribuição dos bens ou serviços infratores, e tais informações devem ser repassadas ao detentor do direito de propriedade intelectual infringido (a única exceção é o acordo chileno, que exige a revelação de tais informações, mas não determina que elas sejam repassadas aos detentores).

Um artigo que resume o conteúdo dos capítulos sobre propriedade intelectual no que diz respeito às responsabilidades das autoridades aduaneiras afirma que:

Em hipótese alguma as autoridades competentes devem ser autorizadas a permitir a exportação de bens contrafeitos ou pirateados, e tampouco devem elas ser autorizadas a permitir que tais bens sejam sujeitados a outros procedimentos alfandegários [...]. (OFFICE OF THE UNITED STATES TRADE REPRESENTATIVE, 2006a, p. 25, tradução nossa). 
Tais determinações aduaneiras se aplicam, inclusive, a bens que estejam somente em trânsito pelo território dos signatários. Nesse aspecto são complementares ao TRIPS pois, embora o acordo multilateral já determinasse que as autoridades aduaneiras poderiam ordenar a destruição de bens contrafeitos ou pirateados apreendidos, ele não incluía os bens em trânsito.

Quando importações ou exportações de produtos infratores são identificadas, as autoridades competentes devem ter o poder de informar os detentores dos direitos de propriedade intelectual correspondentes acerca da identidade do importador e do exportador, bem como a quantidade de bens apreendidos; enquanto os membros dos acordos preferenciais devem necessariamente permitir que suas autoridades forneçam ao detentor as supramencionadas informações, no Acordo TRIPS isso não era obrigatório.

Outra prerrogativa que as autoridades alfandegárias devem ter, conforme os acordos preferenciais, é a de elas suspenderem por conta própria a importação e a exportação de bens suspeitos de infringirem direitos de propriedade intelectual; no Acordo TRIPS as suspensões aduaneiras somente eram previstas quando os detentores dos direitos em questão as solicitavam.

Os acordos preferenciais (com exceção do chileno) determinam que as autoridades judiciárias de seus membros podem realizar ações preventivas através da determinação de que pessoas que estejam prestes a se engajar em atividades infratoras cessem tais atividades antes mesmo que elas sejam concluídas; tal determinação pode envolver tanto apenas o mercado doméstico quanto a exportação e a importação; o Acordo TRIPS era menos específico nesse sentido, ao determinar apenas que suas partes podiam evitar que infrações aos direitos de propriedade intelectual ocorressem, inclusive através de importação.

Ao menos as infrações a direitos de cópia, seus correlatos e a marcas registradas em escala comercial devem ser consideradas crimes (mesmo que sejam feitas sem finalidade lucrativa), e, quando tais atos são identificados, as autoridades podem exercer as ações legais cabíveis ex officio, ou seja, sem que seja necessária uma reclamação prévia. O acordo com o Panamá e o CAFTA-DR são os únicos a afirmar que atividades infratoras que não gerem um dano financeiro mínimo devem ser excluídas da aplicação de procedimentos criminais e do pagamento de reparações. O Acordo TRIPS determina que as penalidades a serem impostas pelos seus membros no caso de ofensas criminais deve ser a imposição de multa ou prisão, e o mesmo se verifica no acordo com o Chile; nos demais acordos preferenciais, os membros devem permitir que tanto prisões quanto imposições de multas sejam aceitas como forma de penalidade. 
Os acordos com a Colômbia e o Peru são os únicos a estender diretamente as penalidades criminais à falsificação de selos destinados à afixação em embalagens de gravações sonoras, cópias de filmes e programas de computador (ou à documentação referente aos últimos). A Colômbia foi a única a se comprometer a acelerar a análise dos pedidos de patentes pendentes; o país sul-americano se comprometeu com os Estados Unidos a, até 31 de dezembro de 2008, aumentar o número de examinadores de patentes e melhorar o treinamento dos mesmos. No mesmo sentido, a República Dominicana se comprometeu a acelerar a resolução de casos de infrações criminais de direitos de cópia sem, entretanto, determinar uma data-limite ou os procedimentos a serem adotados para tanto.

Por fim, uma exclusividade do acordo chileno quanto ao enforcement de direitos de propriedade intelectual é que ele determina que as partes cooperem: em projetos educacionais sobre o uso da propriedade intelectual; em trocas de informações entre seus escritórios de propriedade intelectual; e no desenvolvimento e implementação de sistemas eletrônicos para o gerenciamento dos direitos de propriedade intelectual. Uma provisão próxima, presente no artigo 67 do Acordo TRIPS, determina o intercâmbio entre países desenvolvidos e em desenvolvimento para o estabelecimento ou fortalecimento das instituições domésticas dos últimos, bem como para o treinamento de seus funcionários.

\subsection{Projetos científicos colaborativos}

Somente os acordos com o Peru e com a Colômbia contêm provisões específicas sobre projetos científicos colaborativos; lá se afirma que as partes devem realizar projetos colaborativos de pesquisa científica e apoiar parcerias entre a indústria e instituições de pesquisa públicas e privadas. Para facilitar a consecução de tais projetos, cada país estabeleceu pontos de contato entre instituições: no caso dos Estados Unidos tais instituições são o Office of Science and Technology Cooperation e o Bureau of Oceans and Environmental and Scientific Affairs (ambos submetidos ao Departamento de Estado); no caso do Peru é o Consejo Nacional de Ciencia, Tecnología e Innovación Tecnológica, e no caso da Colômbia é o Instituto Colombiano para el Desarollo de la Ciencia y la Tecnología “Francisco José Caldas”. Tais pontos de contato devem monitorar periodicamente o estado da cooperação entre os países ${ }^{50}$.

50 Embora o Acordo TRIPS tenha como um de seus objetivos expressos a transferência e a disseminação da tecnologia (especialmente aquela partindo de empresas e instituições nos países desenvolvidos em direção a 
4.9 Provisões sobre patentes e resultados das exigências parlamentares estadunidenses de 2007

As requisições feitas pelo Congresso dos Estados Unidos que descrevemos na seção 3 conferiram aos acordos com o Peru, a Colômbia e o Panamá algumas diferenças em relação ao acordo com o Chile e ao CAFTA-DR. Abaixo indicamos quais são tais diferenças, e a quais requisições parlamentares remontam:

- enquanto o acordo com o Chile e o CAFTA-DR delimitam um tempo específico para a proteção de dados de testes submetidos para a aprovação de comercialização de produtos farmacêuticos (de cinco anos), os acordos com Peru, Colômbia e Panamá afirmam que tal período deve ser de "normalmente" cinco anos, o que permite que seus membros concedam um tempo de proteção inferior ao indicado. Tal modificação remonta à exigência parlamentar de que o período de proteção a dados de teste "geralmente" não excedesse o tempo correspondente nos Estados Unidos, e a de que países em desenvolvimento deveriam poder implementar exceções a regras normais de proteção de dados, quando isso fosse necessário para proteger a saúde pública. No mesmo sentido, somente nos três acordos "cobertos" pelo entendimento entre executivo e legislativo de 2007 se afirma que quando dados de testes são importados, o tempo de exclusividade de comercialização concedido no importador deve ser baseado na concessão original, expedida no exterior, de modo que o tempo efetivo de proteção é diminuído.

- todos os acordos de comércio afirmam que os detentores de patentes devem ser compensados por atrasos na concessão das mesmas ${ }^{51}$; o fato de essa afirmação não ser válida nos acordos com o Peru, a Colômbia e o Panamá quanto a produtos farmacêuticos remonta à determinação parlamentar de 2007 de que os acordos de comércio com países em desenvolvimento deveriam ser flexíveis quanto ao tempo a ser adicionado a uma patente em função de atraso na sua concessão. Ademais (diferentemente do verificado no acordo com o Chile e no CAFTA-DR), Peru, Colômbia e Panamá não se comprometeram a estender o tempo de validade de patentes de medicamentos em decorrência de atrasos na aprovação para comercialização dos mesmos.

Apesar das maiores flexibilidades relacionadas a medicamentos que mencionamos acima, há algumas provisões exclusivas aos acordos com Peru, Colômbia e Panamá, e que

países menos desenvolvidos), não há no acordo multilateral provisões detalhadas ou a especificação de pontos de contato para o desenvolvimento de projetos científicos internacionais colaborativos.

51 Considera-se que há atraso quando o pedido de depósito foi feito há mais de cinco anos, ou um pedido de exame de depósito foi feito há mais de três anos. 
podem ser interpretadas como contrárias às orientações gerais determinadas pelo Congresso em 2007: nos três acordos se afirma que o período exclusivo concedido a produtos farmacêuticos patenteados em decorrência de proteção a dados de testes deve permanecer vigente mesmo no caso de ultrapassar o período de vigência da patente dos mesmos. Ademais, somente nos três acordos se afirma que pessoas que demonstrem com sucesso a invalidade de determinada patente farmacêutica devam ser recompensadas por tal ato, e tal recompensa pode incluir a concessão de um período de exclusividade de comercialização do bem protegido pela patente invalidada.

Embora as exigências acerca da "Declaração sobre o Acordo TRIPS e Saúde Pública" feitas nos acordos com o Peru, a Colômbia e o Panamá sejam mais extensas do que as feitas no acordo com o Chile, elas não diferem das feitas no CAFTA-DR.

\subsection{Conclusão}

A comparação entre os capítulos sobre propriedade intelectual dos acordos preferenciais de comércio analisados indica que, apesar de eles serem idênticos em muitos aspectos, eles contêm diversas peculiaridades; entre as seções 4.1 e 4.9 descrevemos as diferenças e complementaridades dos mesmos em relação ao Acordo TRIPS, e enfatizamos as peculiaridades de cada acordo.

Notadamente, os acordos preferenciais realizam, em relação ao Acordo TRIPS, uma atualização das normas sobre propriedade intelectual em decorrência de inovações tecnológicas, o que afeta os direitos de cópia e correlatos. As complementaridades dos acordos preferenciais em relação ao TRIPS se estendem também às patentes, à proteção de dados de testes de produtos farmacêuticos e químicos para agricultura e às marcas registradas. Ademais, os acordos preferenciais realizam especificações, detalhamentos e exigências adicionais ao Acordo TRIPS, tal como a extensão no tempo de validade mínimo dos direitos de marca.

Quando comparados com o Acordo TRIPS, os acordos preferenciais conferem maiores prerrogativas aos detentores de propriedade intelectual quanto ao enforcement dos mesmos e contêm muitas especificações sobre procedimentos aduaneiros (tal como sua extensão aos bens em trânsito).

O acordo entre Estados Unidos e Chile, o primeiro a ser firmado dentre os presentes em nosso recorte, é o que contêm mais diferenças em relação aos demais acordos preferenciais, conforme detalhamos acima; uma consequência particularmente importante 
exclusiva ao acordo chileno é a de atraso no ingresso de medicamentos genéricos no mercado em decorrência da proibição de concessão de autorização para comercialização durante a validade da patente, conforme explicamos acima.

Ademais, os acordos com Peru, Colômbia e Panamá contêm várias diferenças em relação ao CAFTA-DR e ao acordo com o Chile, e tais diferenças remontam diretamente às exigências que o Congresso dos Estados Unidos fez em 2007 ao executivo a fim de que os dois primeiros acordos pudessem ser ratificados, e de que o terceiro pudesse ser concluído; tais exigências são relacionadas às patentes, devido às preocupações dos congressistas com eventuais danos ao acesso a medicamentos e à saúde pública. Embora algumas definições do fast track afirmem que esse tipo de entendimento entre o executivo e o legislativo inclui o compromisso do legislativo em não realizar emendas nos textos negociados pelo presidente, esse exemplo de interferência parlamentar durante a validade do fast track conferido a Bush parece indicar que na prática o Congresso pode requerer uma maior participação no processo de adoção de acordos de comércio, ao menos quando há mudança na maioria partidária (tal como a ocorrida em decorrência das eleições de 2006 nos Estados Unidos, quando a maioria parlamentar deixou de ser republicana para tornar-se democrata).

Houve diferença entre os acordos também: quanto ao nível relativo de exigência de assinatura de outros acordos sobre propriedade intelectual (uma vez que muitos países já eram membros de vários dos acordos requeridos); quanto a transmissões de conteúdos televisivos e retransmissões de sinais de modo ilegal (uma vez que somente a República Dominicana assumiu diversos compromissos específicos sobre o tema); quanto a projetos científicos colaborativos (exclusividade dos acordos com Colômbia e Peru); e sobre recursos genéticos (somente o CAFTA-DR, e os acordos com Peru, Colômbia e Panamá contêm provisões sobre recursos genéticos, e somente os três últimos tratam, ainda que de modo incipiente, de direitos de propriedade intelectual incidentes sobre conhecimentos tradicionais).

Assim, em suma, os capítulos sobre propriedade intelectual dos acordos preferenciais de comércio firmados pelos Estados Unidos com países da América Latina desde a entrada em vigor da OMC, todos eles durante a década de 2000 e durante as presidências de Bush, têm várias diferenças em relação ao Acordo TRIPS, e em diversos aspectos são complementares ao acordo multilateral; por consequência dos acordos preferenciais, os compromissos internacionais sobre a propriedade intelectual de seus signatários foram significativamente aumentados; os capítulos sobre propriedade intelectual dos acordos preferenciais analisados não são uniformes, e as diferenças verificadas em parte decorreram 
de exigências feitas pelo Congresso dos Estados Unidos em 2007, conforme enfatizamos acima.

Ademais, conforme explicamos nas seções 4.3 e 4.5 , algumas provisões dos acordos e de suas side letters são problemáticas porque não esclarecem de que maneira serão interpretadas caso venham a conflitar com direitos de propriedade intelectual ${ }^{52}$.

\section{CONCLUSÃO}

As motivações dos Estados Unidos que, segundo a literatura consultada, levaram o país a assinar seus acordos preferenciais de comércio, apresentadas na seção 3, são compatíveis com a conjectura de Koremenos, Lipson e Snidal (2001) de que os estados controlam o número de atores participantes em instituições a fim de tornar a cooperação sustentável, uma vez que somente em acordos com número bastante restrito de contrapartes (de um, na maioria dos casos, a seis, no caso do CAFTA-DR) os Estados Unidos conseguiram, no período analisado, levar adiante uma liberalização que lhe era satisfatória; tal liberalização incluía normas sobre propriedade intelectual que seriam impossíveis de serem aceitas em nível multilateral naquele momento devido à inexistência de uma zona de acordo quanto ao tema na Rodada Doha de negociações. Desde a perspectiva dos Estados Unidos, a OMC era uma instituição inflexível, uma vez que o país não conseguia modificar o status quo do Acordo TRIPS (alguns países em desenvolvimento, ao contrário, dado que na OMC as decisões são tomadas por consenso, conseguiam não somente barrar as propostas alinhadas à preferência dos Estados Unidos, como também avançar suas propostas, como exemplifica a "Declaração sobre o Acordo TRIPS e Saúde Pública"). Assim, uma vez mais concordando com conjecturas de Koremenos, Lipson e Snidal (2001), os Estados Unidos, impossibilitados de modificar o vínculo entre comércio e propriedade intelectual consolidado na OMC (e insatisfeitos com outros desenvolvimentos na organização multilateral), se voltaram aos acordos preferenciais, instituições diferentes da OMC (por terem, em comparação com a última, um número menor de participantes, uma maior assimetria de poder entre as partes e normas distintas).

Conforme demonstramos na seção 4, diversos compromissos assumidos nos capítulos analisados são diferentes do Acordo TRIPS, ou a ele complementares; portanto, os compromissos internacionais dos membros dos acordos preferenciais analisados são

52 Nesse sentido, Díaz (2008), afirma que os capítulos sobre propriedade intelectual firmados pelos Estados Unidos com países da América Latina no período que analisamos contêm "ambiguidades e vazios". 
diferentes dos compromissos daqueles países que participam apenas do regime multilateral ${ }^{53}$. Tendo em vista que os membros dos acordos preferenciais estudados não deixaram a OMC, as complementaridades dos capítulos sobre propriedade intelectual dos acordos preferenciais estudados certamente se ajustam ao conceito de "TRIPS-plus" que mencionamos na nota de rodapé número 35. Ademais, os capítulos sobre propriedade intelectual aqui analisados impactam as legislações nacionais de um modo não discriminatório, ou seja, os padrões determinados pelos acordos de comércio terão validade sobre os direitos concedidos aos nacionais de quaisquer países.

As dificuldades inerentes a instituições multilaterais, descritas pelas diversas proposições teóricas apresentadas na seção 2, parecem ter se confirmado na OMC, contribuindo para que os Estados Unidos e suas contrapartes (bem como muitos outros traders, como a União Europeia) optassem por firmar acordos preferenciais. Embora a opção por acordos preferenciais tenha se manifestado desde a criação do GATT (e ser permitida por suas regras), ela se intensificou na década de 2000; dela resultaram diversos compromissos sobre propriedade intelectual, dentre os quais estão os aqui analisados.

Os acordos preferenciais de comércio foram também empregados como parte da estratégia de negociação multilateral, já que os países neles envolvidos provavelmente não se oporão à eventual tentativa de extensão ao nível multilateral de padrões regulatórios semelhantes aos dos acordos de comércio dos quais já são parte, o quê, conforme apresentamos na seção 3, foi levado em conta pelos negociadores estadunidenses (e, conforme explicamos na seção 2, essa possibilidade foi teoricamente abordada).

O fato de a maioria dos signatários dos acordos preferenciais firmados pelos Estados Unidos na década de 2000 ser da América Latina é uma evidência em favor dos autores que afirmam que o insucesso da ALCA foi uma das razões que estimularam os Estados Unidos a buscar acordos preferenciais; conforme afirmamos na nota de rodapé número 31, os acordos preferenciais são admitidamente vistos como partes constituintes de uma eventual área de livre-comércio que viria futuramente a abranger todo o continente americano. Nesse sentido, convém enfatizar que a propriedade intelectual esteve entre os temas controversos que impediram que a ALCA fosse concluída.

De modo geral, as motivações estadunidenses para a assinatura dos acordos preferenciais que analisamos foram refletidas no conteúdo sobre propriedade intelectual dos

53 Tomadas em conjunto, as modificações nos direitos de propriedade intelectual dos países signatários de acordos preferenciais gerou o que Polido (2010) descreve como a "fragmentação do direito internacional da propriedade intelectual". 
mesmos. A consideração conjunta das seções 3 e 4 dá suporte a essa afirmação; exemplos desses "reflexos" são a extensão das provisões sobre procedimentos alfandegários a bens em trânsito (haja vista a que, na OMC, não se conseguiu avançar tal proposta), a presença de normas sobre direitos autorais e conexos adaptadas à internet (haja vista ao insucesso na OMPI mencionado na seção 3), e a obrigatoriedade de concessão de períodos de proteção a medicamentos e produtos químicos para a agricultura com base nos dados submetidos para aprovação para comercialização dos mesmos (que remonta à afirmação de Muzaka (2011) de que a concessão obrigatória da proteção a dados de testes estava entre os objetivos estadunidenses, para responder à demanda de suas indústrias farmacêuticas).

Uma vez que, de modo geral, as prerrogativas conferidas aos detentores de direitos de propriedade intelectual foram ampliadas e especificadas, o conteúdo observado nos capítulos sobre propriedade intelectual analisados potencializa os benefícios que tais direitos conferem às indústrias estadunidenses produtoras de bens tipicamente protegidos por direitos de propriedade intelectual, as quais estiveram entre os setores regularmente consultados pelo USTR no período em que ele negociou os acordos preferenciais aqui analisados.

Os Estados Unidos seguem negociando acordos de comércio contendo capítulos sobre propriedade intelectual (e, ademais, as negociações no Conselho do TRIPS da OMC ocorrem regularmente, e lá também os Estados Unidos defendem sua posição em relação aos direitos de propriedade intelectual). Portanto, pode ser interessante, a negociadores comerciais que tenham que lidar com propostas dos Estados Unidos, conhecer o precedente histórico a respeito do tema, ou seja, conhecer o vínculo entre propriedade intelectual e comércio que o país tem defendido, e os resultados que a estratégia empregada para tanto alcançou, em suas interações com os demais estados; portanto, as conclusões do presente artigo têm relevância prática.

Ademais, os acadêmicos interessados nas normas internacionais sobre propriedade intelectual e sobre comércio não podem ignorar a posição dos Estados Unidos quanto às mesmas, uma vez que esse país foi ativo construtor do atual framework multilateral, expandiu sua atividade quanto ao tema ao nível bilateral e regional, e segue adiante com essa abordagem, como as negociações do Trans-Pacific Partnership (recentemente concluídas) e do Transatlantic Trade and Investment Partnership, ainda em curso, indicam.

As possibilidades de pesquisas sobre o tema certamente não estão esgotadas; notadamente, o processo de formulação da política comercial estadunidense recente, em sua interface com a propriedade intelectual, está ainda insuficientemente descrito na literatura. Embora muitos trabalhos afirmem quais são os motivos que levaram os Estados Unidos a 
firmar diversos acordos preferenciais de comércio, e a neles inserir capítulos sobre propriedade intelectual (conforme sintetizamos na seção 3), poucos se dedicam a descrever e analisar o modo como esses motivos se consolidaram domesticamente nos Estados Unidos; embora se saiba que os setores produtivos interessados em direitos de propriedade intelectual tenham manifestado diretamente ao USTR suas intenções em relação aos acordos preferenciais, não encontramos trabalhos que verificassem, por exemplo, se havia convergência entre esses setores produtivos (ou se, ao contrário, havia discordâncias significativas entre eles quanto aos direitos de propriedade intelectual a serem incluídos nos acordos).

Ademais, conforme descrevemos na seção 3, os parlamentares democratas manifestaram, em 2007, oposição a vários pontos dos acordos de comércio em debate para ratificação (o mesmo valendo para os acordos ainda em negociação naquele momento); entretanto, ainda não está totalmente esclarecido como essa divisão partidária dos congressistas em relação aos direitos de propriedade intelectual se formou (haja vista a que Clinton, o presidente democrata antecedente a Bush, firmou um acordo de comércio contendo capítulo sobre propriedade intelectual, o NAFTA ${ }^{54}$ e negociou o acordo de comércio com a Jordânia, que igualmente contém capítulo sobre o tema). Ademais, não encontramos trabalhos específicos sobre os lobbies da propriedade intelectual junto ao legislativo no período estudado, quer seja para influenciar o Congresso durante a construção do conteúdo dos fast track, quer seja durante os debates para ratificação de acordos já firmados. Outra questão interessante, mas ainda carente de respostas, é se o USTR, ao se deparar com diferenças entre as orientações parlamentares e as opiniões manifestadas pelas indústrias, sempre se guia pelas orientações do legislativo, como seria de se esperar.

No presente trabalho analisamos os capítulos sobre propriedade intelectual que os Estados Unidos firmaram com países da América Latina na década de 2000 (tanto em seu aspecto político internacional quanto jurídico), mas reconhecemos que ainda há muitas questões a serem estudadas sobre o tema, conforme explicamos acima. Novas pesquisas são, portanto, desejáveis.

\footnotetext{
54 A negociação do NAFTA foi concluída em dezembro de 1992, durante a presidência de George Herbert Walker Bush ("Bush pai"), mas foi ratificado em 1993 e incorporado definitivamente aos compromissos externos dos Estados Unidos por Clinton.
} 


\section{REFERÊNCIAS}

ABBOTT, F. The Doha Declaration on the TRIPS Agreement and Public Health: lighting a dark corner at the WTO. Journal of International Economic Law, Oxford (GB), v. 5, n. 2, p. 469-505, June 2002.

ALBERTSON, P.C. The evolution of labor provisions in U.S. free trade agreements: lessons learned and remaining questions examining the Dominican Republic - Central America United States Free Trade Agreement (CAFTA-DR). Stanford Law and Policy Review, Stanford, v. 21, n. 3, p. 493-511, June 2010.

BECKER, J.; BLAAS, W. Conclusions: Doha Round and Forum-Switching. In: BECKER, J.; BLAAS W. (Ed.). Strategic arena switching in international trade negotiations. Hampshire (GB): Ashgate, 2007. p. 271-281.

BENTES, P.M. et al. International Trade. The International Lawyer, v. 42, n. 2, p. 323-343, summer 2008.

BHAGWATI, J. Regionalism and multilateralism: an overview. In: MELO, J. de; PANAGARIYA, A. (Ed.). New dimensions in regional integration. Cambridge (MA): Cambridge University Press, 1993. p. 22-51.

; KRISHNA, P.; PANAGARIYA, A. The world trade system: trends and challenges. 2014. Disponível em: <http://indianeconomy.columbia.edu/sites/default/files/paper1the_world_trading_system.pdf $>$. Acesso em: 13 ago. 2015.

CELLI JUNIOR, U.; CACCIAMALI, M.C.; BOBIK, M. Em busca de uma nova inserção da América Latina na economia global. Estudos Avançados, São Paulo, v. 26, n. 75, p. 91-110, maio - ago. 2012.

CESAR, S.E.M.; SATO, E. A Rodada Doha, as mudanças do regime do comércio internacional e a política comercial brasileira. Revista Brasileira de Política Internacional, Brasília, v.55, n.1, p.174-193, 2012.

CHOREV, N. Political and institutional manoeuvres in international trade negotiations: the United States and the Doha Development Round. In: BECKER, J.; BLAAS W. (Ed.).

Strategic arena switching in international trade negotiations. Hampshire (GB): Ashgate, 2007. p. 33-65.

CORREA, C.M. O Acordo TRIPS e o acesso a medicamentos nos países em desenvolvimento. SUR - Revista Nacional de Direitos Humanos, São Paulo, v.2, n.3, p. 2639, dez. 2005.

. The push for stronger enforcement rules: implications for developing countries. In: FINK, C.; CORREA, C. M. (Ed.). The global debate on the enforcement of intellectual property rights and developing countries. Geneva (Switzerland): International Centre for Trade and Sustainable Development, 2008. p. 27-80. 
DEERE, C. The implementation game: the TRIPS Agreement and the global politics of intellectual property reform in developing countries. New York: Oxford University Press, 2009.

DENT, C.M. Paths ahead for East Asia and Asia-Pacific regionalism. International Affairs, Oxford (GB), v. 89, n. 4, p. 963-985, July 2013.

DÍAZ, Á. América Latina y el Caribe: la propiedad intelectual después de los tratados de libre comercio. Santiago de Chile: Naciones Unidas, 2008.

FINK, C.; REICHENMILLER, P. Tightening TRIPS: intellectual property provisions of U.S. free trade agreements. In: NEWFARMER, R. (Ed.). Trade, Doha and development: a window into the issues. Washington (DC): The International Bank for Reconstruction and Recovery; Washington (DC): The World Bank, 2006. p. 285-303.

FRIEDEN, J. A. Actors and Preferences in International Relations. In: LAKE, D.A.; POWELL, R. (Ed.). Strategic Choice and International Relations. Princeton (NJ): Princeton University Press, 1999. p. 39-76.

GENERAL AGREEMENT ON TARIFFS AND TRADE. Agreement on trade-related aspects of intellectual property rights. 1994. Disponível em: <https://www.wto.org/english/docs_e/legal_e/27-trips.pdf>. Acesso em: 31 jul. 2015.

GILLMAN, E. Legal transplants in trade and investment agreements: understanding the exportation of U.S. law to Latin America. Georgetown Journal of International Law, Washington (D.C.), v. 41, n. 1, p. 263-301, 2009.

GOLDSMITH, J.L.; POSNER, E.A. The limits of international law. New York: Oxford University Press, 2005.

KAHLER, M. Multilateralism with small and large numbers. International Organization, Cambridge (MA), v. 46, n. 3, p. 681-708, summer 1992.

LANTIS, J.S. Leadership matters: international treaty ratification in Canada and the United States. The American Review of Canadian Studies, Washington (D.C.), v. 35, n. 3, p. 38341, autumn 2005.

MARTIN, L. L. Coercitive cooperation: explaining multilateral economic sanctions. $378 \mathrm{f}$. Tese (Doutorado em Political Science) - Harvard University Department of Government, Cambridge (MA), 1989.

MASTEL, G. Fast track revival: suddenly both U.S. presidential contenders are interested in fast-track authority. The International Economy, Washington (D.C.), summer 2012.

Summer 2006.

; SHAPIRO, H. Fast track forever? The International Economy, Washington (D.C.),

MICARA, A.G. Trips-plus border measures and access to medicines. The Journal of World Intellectual Property, v. 15, n. 1, p. 73-101, Jan. 2012. 
MORROW, J.D. The strategic Setting of Choices: Signaling, Commitment, and Negotiation in International Politics. In: LAKE, D.A.; POWELL, R. (Ed.). Strategic Choice and International Relations. Princeton (NJ): Princeton University Press, 1999. p. 77-114.

MUZAKA, V. The politics of intellectual property rights and access to medicines. Hampshire (GB): Palgrave Macmillan, 2011.

NOEHRENBERG, E. The realities of TRIPS, patents and access to medicines in developing countries. In: PUGATCH, M. P. (Ed.). The intellectual property debate: perspectives from Law, Economics and Political Economy. Cheltenham (UK): Edward Elgar, 2006. p.170-186.

OFFICE OF THE UNITED STATES TRADE REPRESENTATIVE. Bipartisan Agreement on Trade Policy. 2007a. Disponível em:

<http://www.ustr.gov/sites/default/files/uploads/factsheets/2007/asset_upload_file127_11319. pdf> Acesso em: 22 jan. 2015.

United States - Panama Trade Promotion Agreement. 2007b. Disponível em: < https://ustr.gov/trade-agreements/free-trade-agreements/panama-tpa/final-text $>$. Acesso em: 31 jul. 2015.

United States - Colombia Trade Promotion Agreement. 2006a. Disponível em: < https://ustr.gov/trade-agreements/free-trade-agreements/colombia-fta/final-text>. Acesso em: 31 jul. 2015.

. United States - Peru Trade Promotion Agreement. 2006b. Disponível em: < https://ustr.gov/trade-agreements/free-trade-agreements/peru-tpa/final-text $>$. Acesso em: 31 jul. 2015.

United States - Dominican Republic - Central America Free Trade Agreement. 2004. Disponível em: < https://ustr.gov/trade-agreements/free-tradeagreements/cafta-dr-dominican-republic-central-america-fta/final-text $>$. Acesso em: 31 jul. 2015.

. United States - Chile Free Trade Agreement. 2003. Disponível em:

<https://ustr.gov/trade-agreements/free-trade-agreements/chile-fta/final-text>. Acesso em: 31 jul. 2015.

PHARMACEUTICAL RESEARCH AND MANUFACTURERS OF AMERICA. About Phrma. 2015. Disponível em: <http://www.phrma.org/about>. Acesso em: 24 jan. 2015.

POLIDO, F.B.P. Contribuições ao estudo do Direito Internacional da Propriedade Intelectual na era pós-Organização Mundial do Comércio: fronteiras da proteção, composição do equilíbrio e expansão do domínio público. 521f. Tese (Doutorado em Direito)-Departamento de Direito Internacional e Comparado da Faculdade de Direito da Universidade de São Paulo, São Paulo, 2010.

SCHOTT, J. J. Assessing US FTA policy. In: SCHOTT, J.J. (Ed.). Free trade agreements: US strategies and priorities. Washington (D.C.): Institute for International Economics, 2004. p.359-381. 
SELL, S. Private power, public law: the globalization of intellectual property rights. New York: Cambridge University Press, 2003.

. TRIPS-Plus free trade agreements and access to medicines. Liverpool Law Review, v. 28, n. 1, p. 41-75, Apr. 2007.

SNIDAL, D. The Game Theory of International Politics. World Politics, Princeton (NJ), v. 38, n. 1, p. 25-57, Oct. 1985a.

. Coordination versus Prisoners' Dilemma: Implications for International Cooperation and Regimes. The American Political Science Review, Denton (TX), v. 79, n. 4, p. 923-942, Dec. $1985 b$.

; KOREMENOS, B.; LIPSON, C. The rational design of international institutions. International Organization, Cambridge (MA), v. 55, n. 4, p. 761-799, autumn 2001.

SWISS FEDERAL INSTITUTE OF INTELLECTUAL PROPERTY. Anti-Counterfeiting Trade Agreement (ACTA). 2014. Disponível em: <https://www.ipi.ch/en/legal-info/legalareas/counterfeiting-piracy/acta.html>. Acesso em: 26 jan. 2015.

TANG, Y.S. Bilateral versus multilateral strategies in the promotion of technology transfers to developing countries. 296f. Tese (Doutorado em Comparative Analysis in Institutions, Economics and Law) - Universiteit Gent, Gent, 2010.

UNITED STATES SENATE. Treaties. 2015. Disponível em:

<www.senate.gov/artandhistory/history/common/briefing/Treaties.htm>. Acesso em: 14 jan. 2015.

; THE HOUSE OF REPRESENTATIVES OF THE UNITED STATES OF

AMERICA. Trade Act of 2002. 2002. Disponível em:

<http://www.gpo.gov/fdsys/pkg/BILLS-107hr3009enr/pdf/BILLS-107hr3009enr.pdf>. Acesso em: 21 jan. 2015.

WORLD TRADE ORGANIZATION. Implementation of paragraph 6 of the Doha Declaration on the TRIPS Agreement and public health: Decision of the General Council of 30 August 2003. 2003. Disponível em:

<http://www.wto.org/english/tratop_e/trips_e/implem_para6_e.htm>. Acesso em: 18 jan. 2013.

Declaración relativa al acuerdo sobre los ADPIC y la salud pública. 2001.

Disponível em:

<https://www.wto.org/spanish/thewto_s/minist_s/min01_s/mindecl_trips_s.htm>. Acesso em: 31 jul. 2015.

WTO members approve TRIPS extension for developing countries. Intellectual Property \& Technology Law Journal, New York, v. 15, n. 2, Feb. 2003.

WU, M. et. al. The proliferation of regional trade agreements: (re-)shaping the trade landscape with multilateralism on pause. American Society of International Law Proceedings, Washington (D.C.), v. 107, 2013. 